\title{
Nález časně eneolitické tzv. těžké měděné industrie z Moravského krasu na Blanensku
}

\section{Finding of the early Eneolithic so-called heavy copper industry from the Moravian Karst in the Blansko region}

\author{
Jaroslav Peška / Milan Salaš
}

\begin{abstract}
Abstrakt
Př́klad ojedinělého nálezu (nebo monodepozita) zástupce tzv. těžké měděné industrie z doby časného eneolitu na Moravě ve formě sekery s kř́žovým ostřím typu Jászladány z netypické polohy (prudký svah pod přirodní skálou v blízkosti malé jeskyňky) v prostředí atraktivní a výjimečné sídelní oblasti střední části Moravského krasu z katastru Babic nad Svitavou. Artefakt rozšiřuje kolekci ca 15 analogických kusů z Moravy a Slezska. Sekera je "zdobena” raženými kruhovými znaky na vnitřni straně okolo násadního otvoru s náznakem oboustranné tulejky. Podobné ražené znaky evidujeme na časně eneolitických sekeromlatech a sekerách s křižovým ostřím především v oblasti Karpatské kotliny, z níž pochází také většina typologických obdob. Význam ražeb vysvětlujeme označením jisté míry prestiže nebo obchodovatelnosti artefaktu rostoucí úměrně s počtem znaků. Zdůrazňuje tak prestižní a mocenskou hodnotu artefaktu, v nichž spatřujeme hlavní význam a funkci předmětu. Vyrobena byla z čisté mědi se stopami střibra a niklu s pưvodem snad v Sedmihradsku.
\end{abstract}

\section{Klíčová slova}

Moravský kras, časný eneolit, jordanovská kultura, sekera s křížovým ostřím typu Jászladány, ražené znaky

\begin{abstract}
Example of a unique find (or monodeposit) of a representative of the so-called heavy copper industry from the Early Eneolithic period in Moravia in the form of axe-adze of Jászladány type from an atypical location (steep slope under a natural rock near a small cave) in an attractive and exceptional settlementl area of the central part of the Moravian Karst from the cadastre of Babice nad Svitavou. The artifact expands the collection of about 15 analogous pieces from Moravia and Silesia. The axeadze is "decorated" with embossed circular signs on the inside around the handle opening with a hint of double-sided socket. We record similar embossed signs on early Eneolithic axes and axes-adzes, especially in the area of the Carpathian Basin, from which most typological periods also come. We explain the significance of embossments by designating a certain degree of prestige or tradability of an artifact increasing in proportion to the number of characters. It emphasizes the prestigious and power value of the artifact, in which we see the main meaning and function of the object. It was made of pure copper with traces of silver and nickel, probably originating in Transylvania.
\end{abstract}

\section{Key words}

Moravian Karst, early Eneolithic, Jordanów Culture, axe-adze of Jászladány type, embossed signs 


\section{1. Úvod}

Poměrně bohatá moravská kolekce těžkých měděných artefaktů (sekeromlaty, sekery s křížovým ostřím, ploché sekery) z počátku eneolitu (Dobeš et al. 2019; Peška 2020) byla obohacena dalším ojedinělým nálezem měděné sekery s křížovým ostřím z katastru Babic nad Svitavou (okr. Blansko) v zajímavém regionu střední části Moravského krasu (nález pochází ze svahu naproti slavné jeskyni Býčí skála). Jako většina detektorových nálezů ohlášených nebo odevzdaných post quem je, přes relativně podrobné nálezové okolnosti (viz níže), náš nález ochuzen o možnost autentického vyzvednutí. Dodatečně, v únoru 2000, byl samotný terén za př́tomnosti nálezce a jednoho z autorů př́spěvku pouze rekognoskován (obr. 1). Jak můžeme číst dále, byla cesta od nálezce po sbírkotvornou instituci poněkud zdlouhavá. Je to však ukázka toho lepšího případu, kdy se artefakt nakonec přece jen do sbírek muzea dostane a nestane se předmětem nelegálního obchodování.

\section{Nálezové okolnosti a topografická situace}

Při povrchovém průzkumu strmého severovýchodního svahu na levobřeží Křtinského potoka naproti Býčí skále nalezl pomocí detektoru R. Lang z Rakouska (2640 Gloggnitz) v listopadu 1999 izolovaně uložený měděný artefakt - sekeru s křížovým ostř́m. Podle administrativně správního členění byl nález učiněn na severoseverovýchodním okraji katastru Babice nad Svitavou (okr. Blansko), a to přibližně 250 m SV od kóty Jelenec (509 m) v nadmořské výšce cca $415 \mathrm{~m}$, asi $70 \mathrm{~m}$ jihozápadně od skály Jidáška (obr. 1) a 6 m jižně od osamoceného skaliska s malou bezejmennou jeskyňkou č. 1202 v povrchové vrstvě lesního humusu a hloubce
10-20 cm. V r. 2011 předal nálezce sekeromlat do sbírek Moravského zemského muzea.

Místem nálezu je poměrně prudký severovýchodní svah nad údolím Křtinského potoka (obr. 2) s vysokou hodnotou nadmořské výšky (415 m), když vrchol kopce Jelenec se nachází ve výšce $509 \mathrm{~m}$. Zajímavým krajinným kontextem je blízkost skaliska (v krasové oblasti jinak běžné) a zejména malé bezejmenné jeskyňky (č. 1202) (obr. 3). Nálezy kovových artefaktů ve formě depotů nebo monodepozit $\mathrm{z}$ doby bronzové se dost často váží na nápadné přírodní útvary a tato skutečnost není náhodná a je dostatečně známá (Salaš 2005, 195 ad.; Jiráň 2008, 14 ad.; Chvojka et al. 2017, 201 ad.). I když tento jev jsme zatím v eneolitu ve větší míře nepozorovali, nelze do budoucna tuto možnost a priori vyloučit. Prozatím nejsme schopni rozhodnout, zda se ve specifickém prostředí Moravského krasu jedná o výjimku, nebo o pravidlo. To mohou rozhodnout teprve budoucí objevy a jejich nálezové situace. Osamocené nálezy mimo sídlištní kontexty, dříve považované za ztracené (takovou náhodu lze u skoro $1 \mathrm{~kg}$ vážícího artefaktu snad vyloučit), je možno zařadit do kategorie topographische Einzelfunde nebo cestovní obětiny (Wegeopfer) a v tomto smyslu by nález bylo možno klasifikovat i jako monodepozitum.

\section{Popis sekery}

Sekera s krŕížovým ostřím a s centrálně umístěným, po obvodu na obou plochách věncovitě zesíleným a lehce tulejkovitě protaženým otvorem, v podélné ose obloukovitě zakřivené tělo plankonvexního profilu v horní partii výrazněji prohnuto, uprostřed v maximální šíri těla se boky sbíhají téměř do hrany, příčný obloukovitý břit ostrý a lehce asymetrický (do pravého boku přechází plynule, na levoboku je odsazen hranou), svislý břit rovněž ostrý a výrazně 


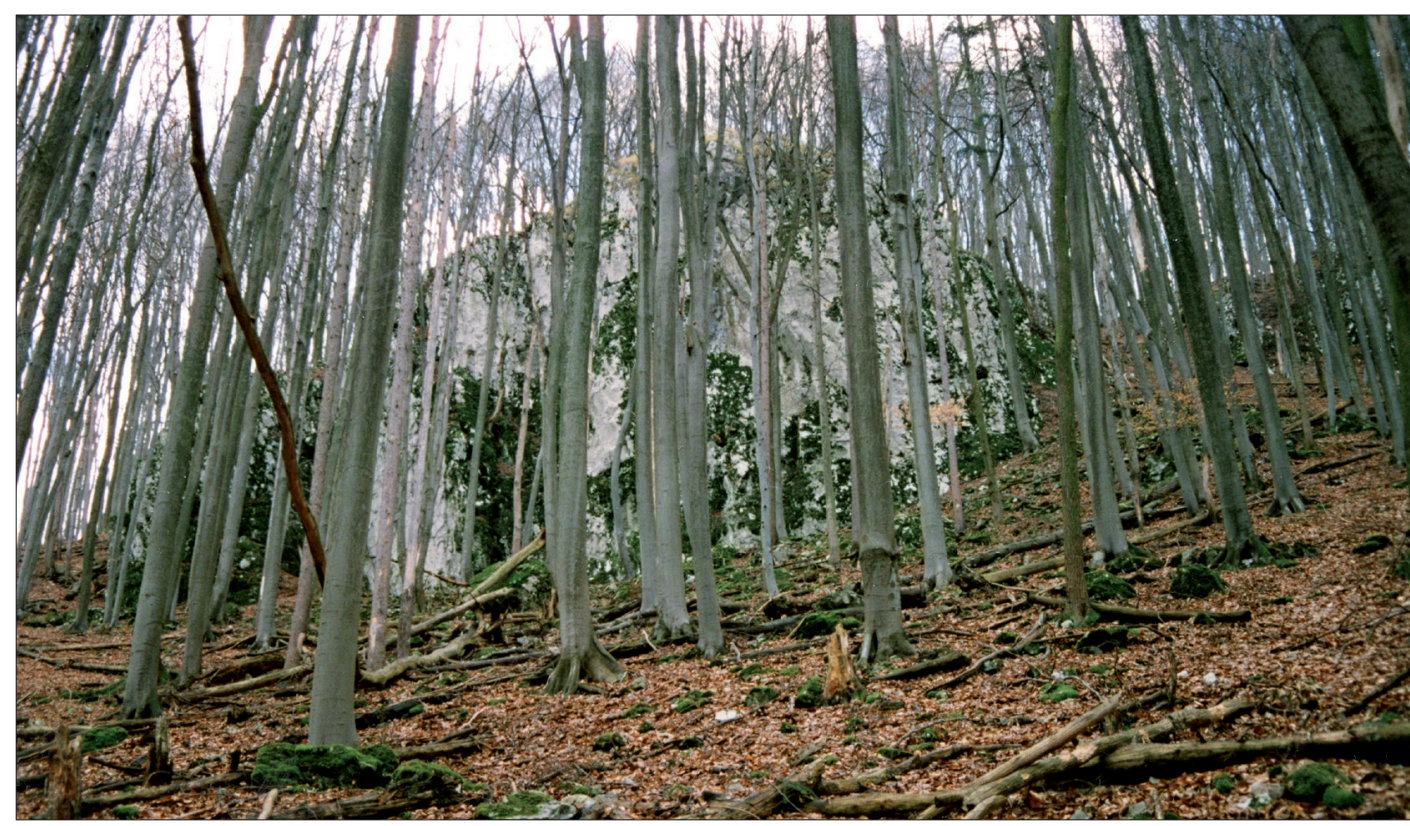

Obr. 1: Babice nad Svitavou - Jelenec. Skalní stěna Jidáška, nedaleko které byla uložena měděná sekera. Foto M. Salaš.

Fig. 1: Babice nad Svitavou - Jelenec. Cliff Jidáška, in the vicinity of which the copper pickaxe was deposited. Photo M. Salaš.

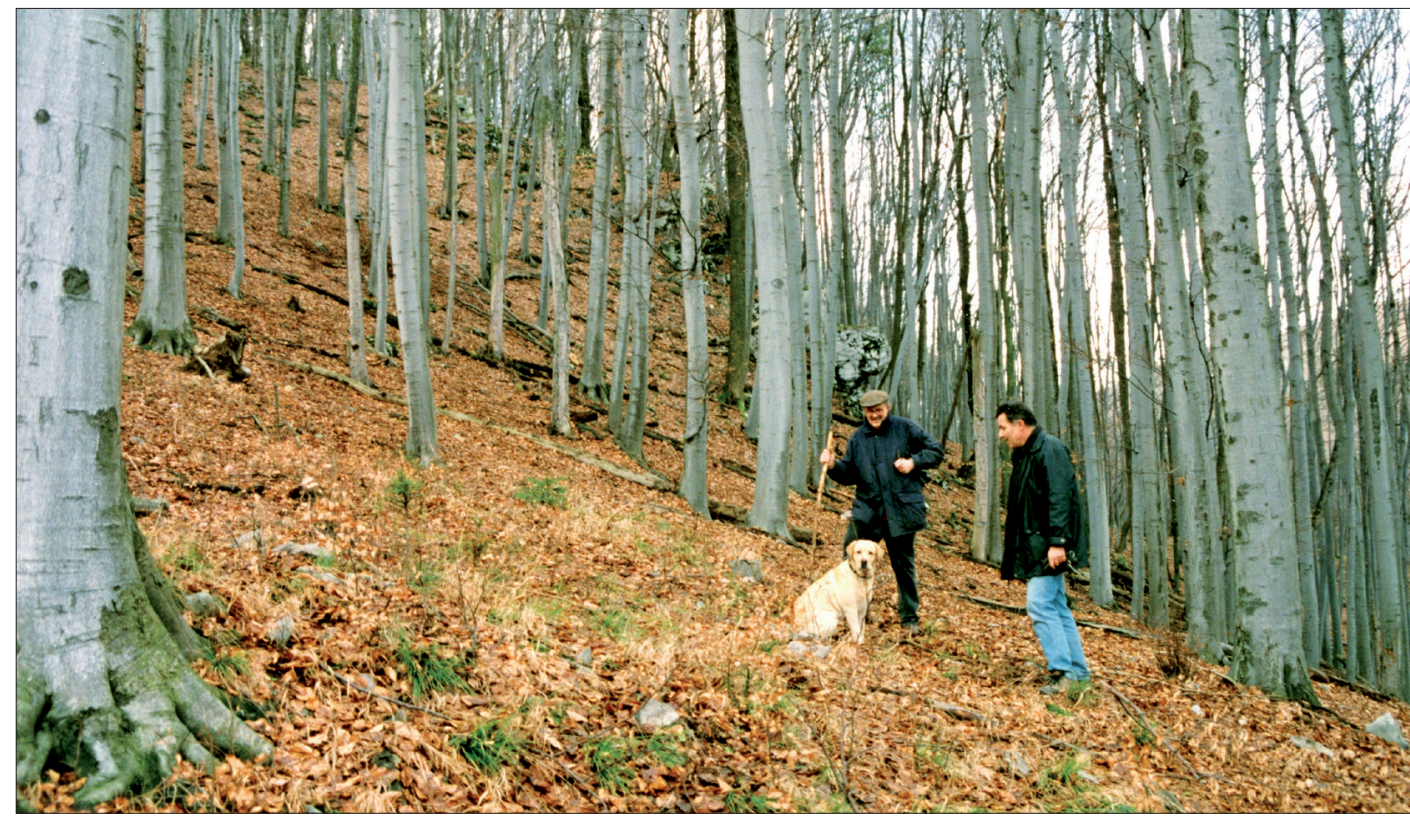

Obr. 2: Babice nad Svitavou - Jelenec. Osoby na místě nálezu měděné sekery na prudkém svahu naproti jeskyni Býčí skála. Foto M. Salaš.

Fig. 2: Babice nad Svitavou - Jelenec. People at the findspot of the copper pickaxe on a steep slope across from the Býčí skála Cave. Photo M. Salaš. 


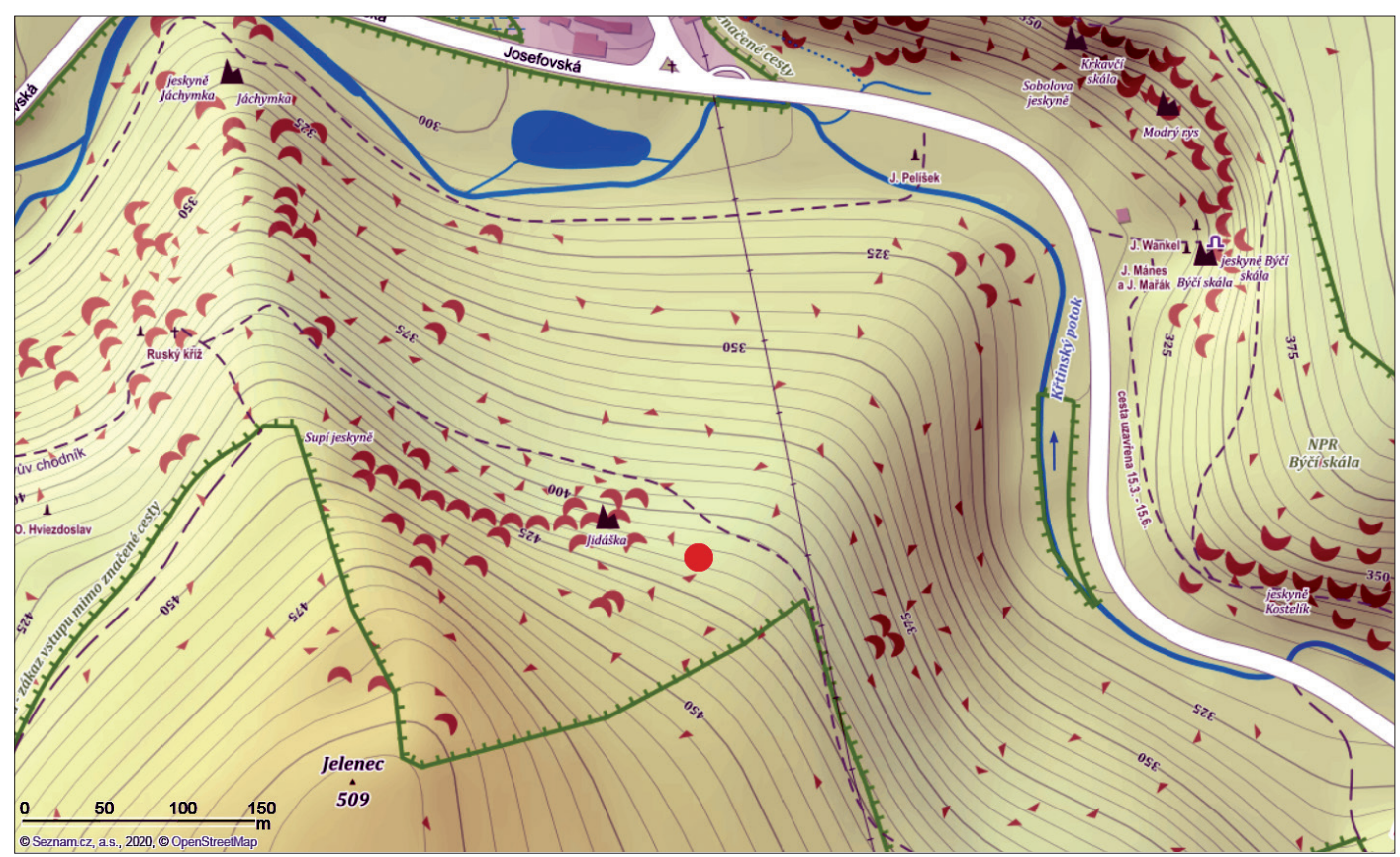

Obr. 3: Babice nad Svitavou - Jelenec. Poloha nálezu sekerky označena červeným kolečkem. Mapový podklad: http://www.mapy.cz.

Fig. 3: Babice nad Svitavou - Jelenec. Findspot of the pickaxe, marked with a red circle. Base map: http://www. mapy.cz.

asymetricky zaoblený, spodní hranou výrazně ukloněný zpět k otvoru. Na tmavě červeném až červenohnědém povrchu místy, především na dorsální ploše, povlaky světle zelené patiny, na ní lokálně (zejména kolem otvoru na dorsální ploše) krusty žlutozelené až žlutohnědé patiny. Na bazální ploše kolem otvoru směrem k oběma břitům symetricky rozmístěno šest mělkých důlků o průměru 4-5 mm (hl. max. $1 \mathrm{~mm}$ ) potažených světle zelenou patinou, na níž je v pěti důlcích (3 ke svislému břitu, 2 k příčnému břitu) ještě zřetelný, i když místy již setřelý, sytě žlutý až světle žlutohnědý (kovový?) povlak. D. $23,6 \mathrm{~cm}$, max. š. $5,8 \mathrm{~cm}$, š. břitů 4,6 a $3,2 \mathrm{~cm}$, hmot. 881 g (obr. 4-6).

\section{Sekera s křížovým ostřím a její širší nálezový kontext}

Zkoumaný měděný artefakt lze jednoznačně zařadit do skupiny seker s křížovým ostřím. Tyto dvojramenné sekery vykazují při čelním pohledu břity postavené do podoby křiže, přičemž svislý břit lze považovat za ostří, zatímco příčný za týlovou část. Objevují se na velice širokém teritoriu od Sardinie a Kréty, v Palestině a od Mezopotámie až po Indus, Kavkaz a Tádžikistán v různých časových pásmech. V Evropě jsou nejhojnější a nejstarší v balkánsko-karpatském okruhu od poloviny 5. tis. př. n. 1. a jednoznačná je tendence vyznívání směrem k SZ, takže Morava a Čechy i s východní částí Německa se tak stávají okrajovou zónou rozšíření. Původ se dnes hledá v autonomním evropském kontextu rozšíření sekeromlatů typu Vidra na území 

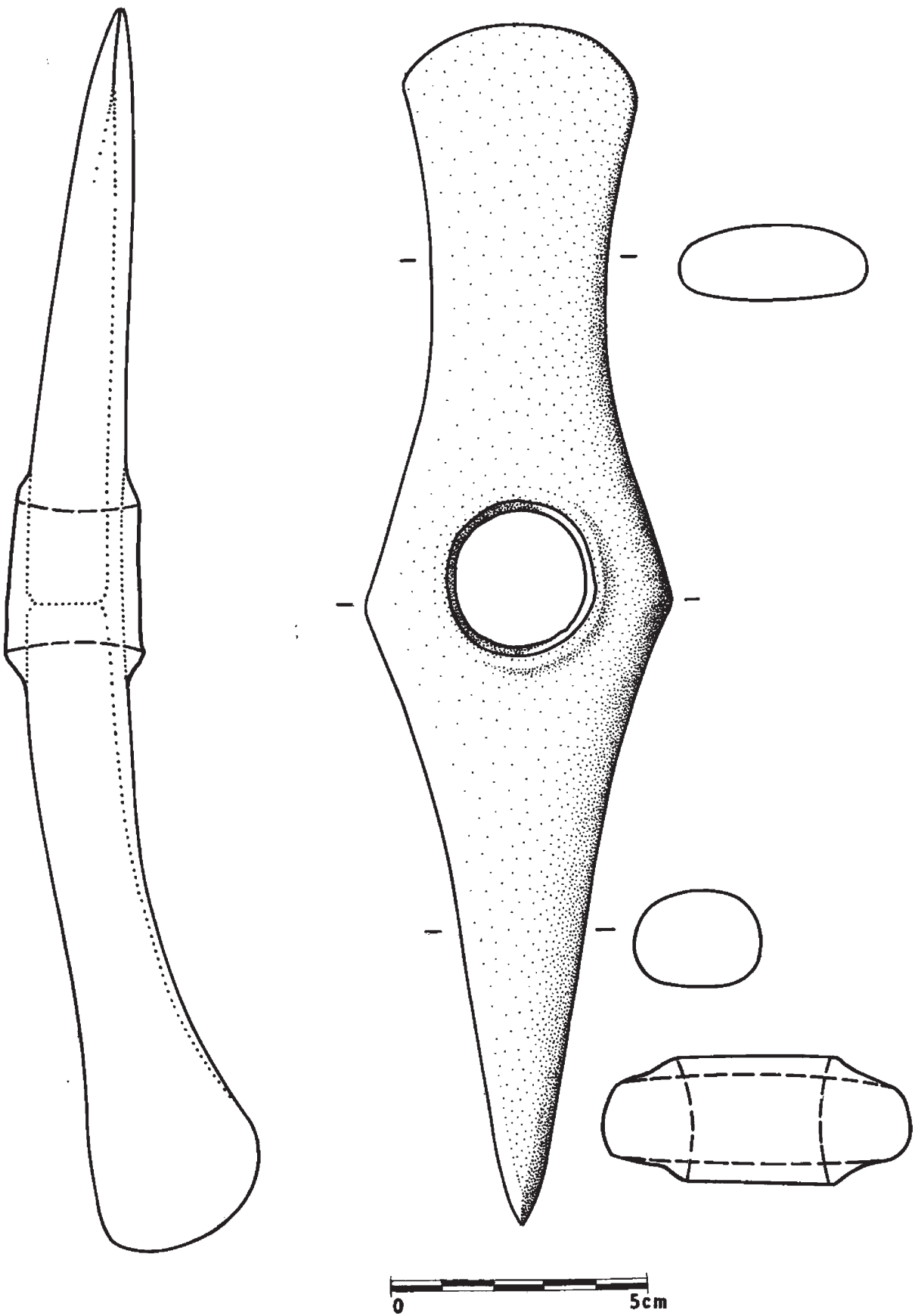

Obr. 4: Babice nad Svitavou - Jelenec. Sekera s křížovým ostřím typu Jászladány. Kresba M. Chylíková. Fig. 4: Babice nad Svitavou - Jelenec. Pickaxe of type Jászladány. Drawing M. Chylíková. 


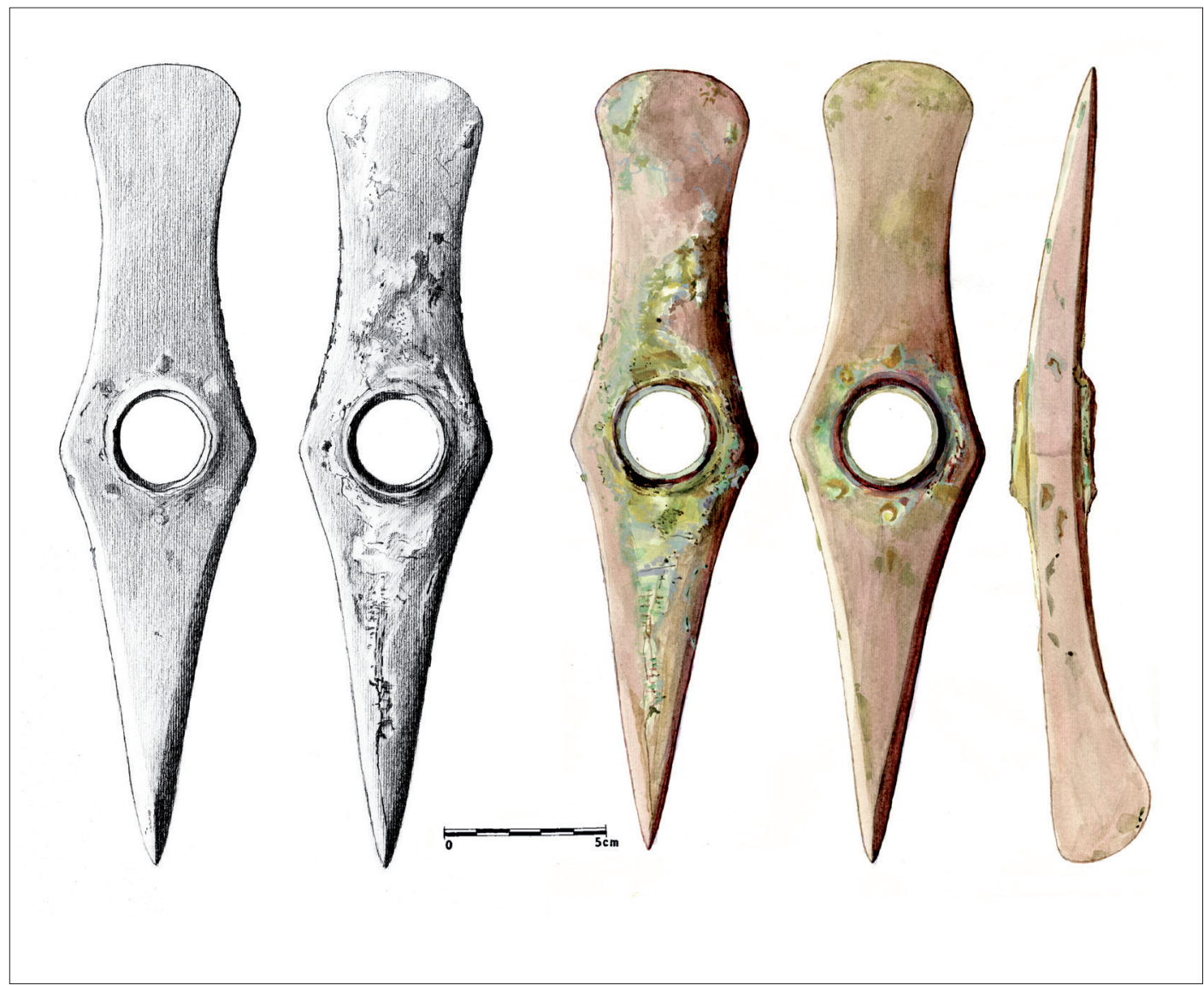

Obr. 5: Babice nad Svitavou - Jelenec. Sekera s křízovým ostřím typu Jászladány. Kresba M. Chylíková.

Fig. 5: Babice nad Svitavou - Jelenec. Pickaxe of type Jászladány. Drawing M. Chylíková.

kultur Cucuteni - Gumelnița - Karanovo VI, kde najdeme i spojovací článek mezi sekeromlaty a nejstaršími sekerami s křížovým ostřím typu Ariuşd (Vulpe 1975, 33-34; Dobeš 2013, 20). Nálezovým prostředím jsou hrobové celky, depoty a převaha ojedinělých nálezů. Funkčně jsou spojovány s hornickou nebo tesařskou činností (nástroje), zbraněmi nebo odznaky statutárních symbolů (Boroffka 2009, 246-251). Jakákoliv absence pracovních stop na povrchu většiny artefaktů by jejich praktické použití nepodporovala.

\subsection{Terminologie a typologie}

Terminologicky se nakonec v českém prostředí ustálil termín (asi nejvýstižnější) sekery s kř́ižovým ostř́m (Novotná 1955, 510). V německy psané literatuře pak oscilují termíny jako Hackenäxte, kreuzschneidige Äxte nebo kreuzschneidige Hackenäxte (Novotná 1970; Vulpe 1975; Todorova 1981; Patay 1984; Antonović 2014). Při popisu se někdy místo břitu a týlu používají termíny horizontální a vertikální rameno, když určující je osa břitu (Dobeš 2013, 20).

Postupné vyčleňování (Driehaus 1952, 3; Schubert 1965, 280-282) vyústilo v uznávanou 


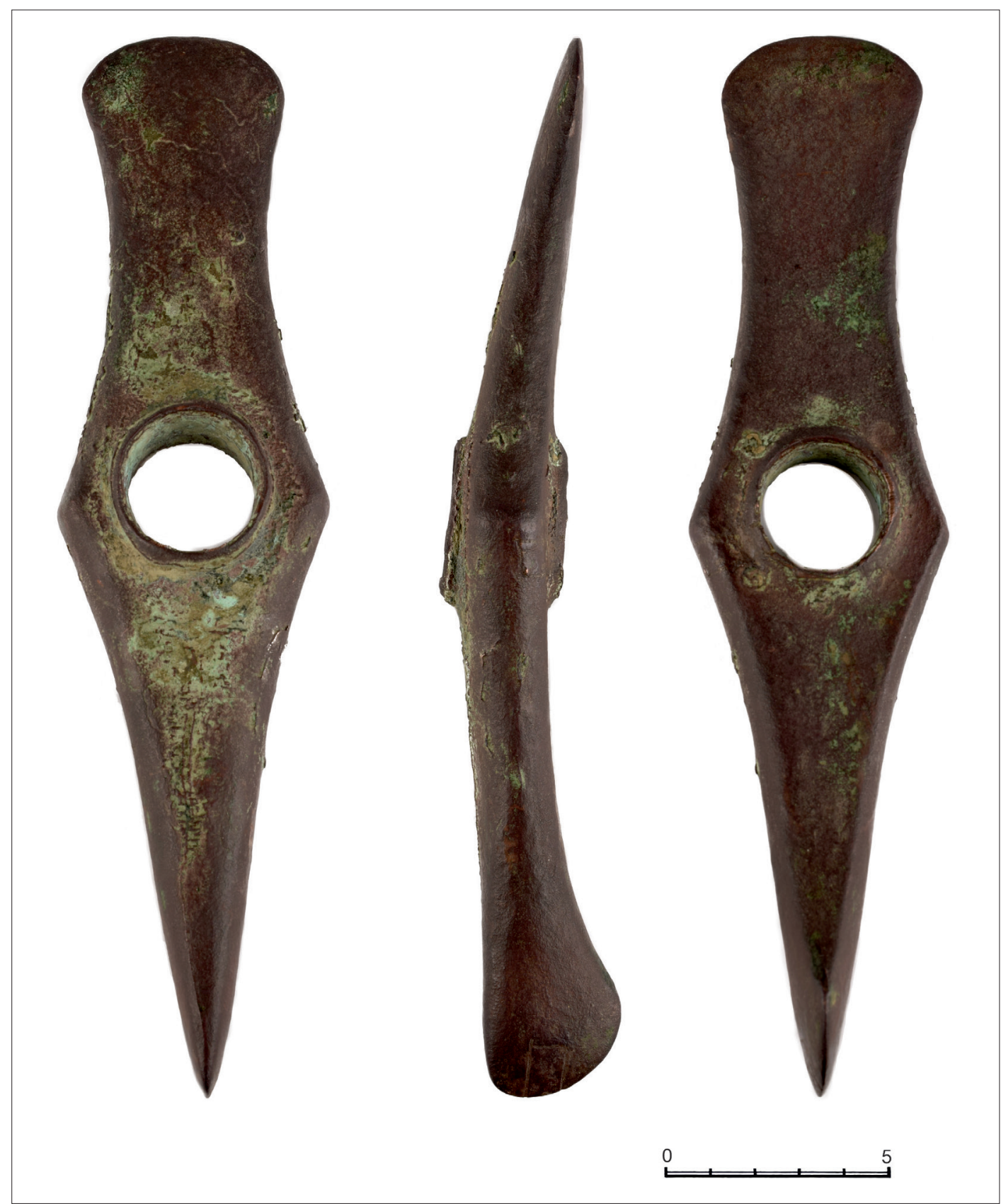

Obr. 6: Babice nad Svitavou - Jelenec. Sekera s křížovým ostřím typu Jászladány. Foto M. Kršková.

Fig. 6: Babice nad Svitavou - Jelenec. Pickaxe of type Jászladány. Photo M. Kršková. 
typologii A. Vulpeho (1975, 33), který původní Driehausovy vyvinuté sekery typu Jászladány rozdělil ještě na další lokální typy (Nógrádmarcal, Kladari, Čepin a Tîrgu Ocna) a typ Jászladány na řadu variant (Vulpe 1975, 37-48), což doplnil P. Patay (1984, 67-89) a je používáno dodnes. Na počátku vývojové řady stojí typ Ariuşd současný s nejstarší skupinou sekeromlatů tiszapolgárské kultury. Typ Jászladány je propojen s bodrogkeresztúrskou formací, a to díky opakovanému výskytu v hrobech, současný je také ne tak výrazně profilovaný typ Nógrádmarcal (společný výskyt v depotu z Roudnice: Dobeš 2013, 21-22, tab. 4: 2-3). Časově lze oba typy v našich poměrech spojovat s jordanovskou kulturou a tím pádem s 2 . horizontem výskytu měděné industrie na Moravě (Peška v tisku).

\subsection{Babice nad Svitavou - Jelenec}

Exemplář z Babic nad Svitavou (obr. 4-6) náleží jednoznačně do skupiny seker s kř́ížovým ostř́im. Díky svému vyhraněnému tvaru jej řadíme k typu Jászladány s prvky typu Nógrádmarcal. K této úvaze nás vede méně prohnutá boční podélná osa artefaktu a asymetricky zaoblené ostř́i (příčný břit), což je pro tento typ charakteristické (Nová Dědina, Skrbeň, Štramberk?, Litoměřice, Roudnice, Malé Leváre ad.). Ve prospěch typu Jászladány také hovoří ostřejší profilace a hranění bokủ s obloukovitým ukončením týlové části, když náznak tulejkovitého otvoru (oboustranného) nacházíme u obou typů. Méně snadné je pak jednoznačné zařazení k variantě typu Jászladány. Přikláníme se sice k variantě Petreşti (typická var. Bradu má až extrémně vějířovitě rozšířený týl - př́ičný břit), jsme si však vědomi značné variability mezi jednotlivými varietami, kdy není problém zjistit na jednom artefaktu znaky více variant, takže se skoro zdá, že takové podrob- né členění je nadbytečné. Také z toho důvodu nejsme nakloněni vyčlenit další varietu na pomezí obou typů.

\subsection{Analogické nálezy a rozšíření}

Na Moravě v současnosti evidujeme celkem 24 kusů seker s křížovým ostřím, včetně fragmentů (Dobeš et al. 2019, 30). Většina (79,17 \%) náleží k typu Jászladány, zbytek k typu Nógrádmarcal (20,83 \%). Nejvýraznější je depot 3 exemplářů z Velkých Losin (Halama 2015; Dobeš et al. 2019, $30)$, kde autoři nejnovější studie přisuzují dva kusy variantě Petreşti (Dobeš et al. 2019, obr. 3: 2-3) a jeden variantě Bradu (Doběs et al. 2019, obr. 3: 1). Další exemplář je zastoupen v nově objeveném depotu z Moravského Krumlova (nepubl.). Zbytek pochází z ojedinělých nálezů, včetně dvou kusů z Hodonína (Dobeš et al. 2019, tab. 1). Pozorovatelná je koncentrace typu Jászladány na východní Moravě (obr. 7) se dvěma excentricky položenými nalezišti na Znojemsku (Plaveč, Moravský Krumlov) a depotem z Velkých Losin, nacházejícím se značně severním směrem v podhůří Jeseníků. Nový nález z Babic nad Svitavou v Moravském krasu tak vytváŕí pomyslnou spojnici posledně jmenovaných nalezišt ve stř̌ední části západního okraje rozšsiřrení těžkých eneolitických měděných předmětů na Moravě a ve Slezsku (Dobeš et al. 2019, obr. 1). Menší počet zástupců typu Nógrádmarcal najdeme v Pomoraví (obr. 7) a pro dálkové komunikace je důležitý kus z Kotouče u Štramberka v Moravské bráně (Šikulová - Zápotocký 2010, obr. 5: 4). Nedávný nález ze sídlištní jámy v Přerově - Dluhonicích (bez dalšího doprovodného materiálu; laskavá informace J. Vrány) jen potvrzuje dosavadní koncentraci. Tento nález však bude teprve vyhodnocen. Směrem do Čech sledujeme jasnou nižší koncentraci seker s křížovým ostřím a poměr je zde opačný, nebot jen 2 artefakty náleží k typu Jászladány (Roudnice 


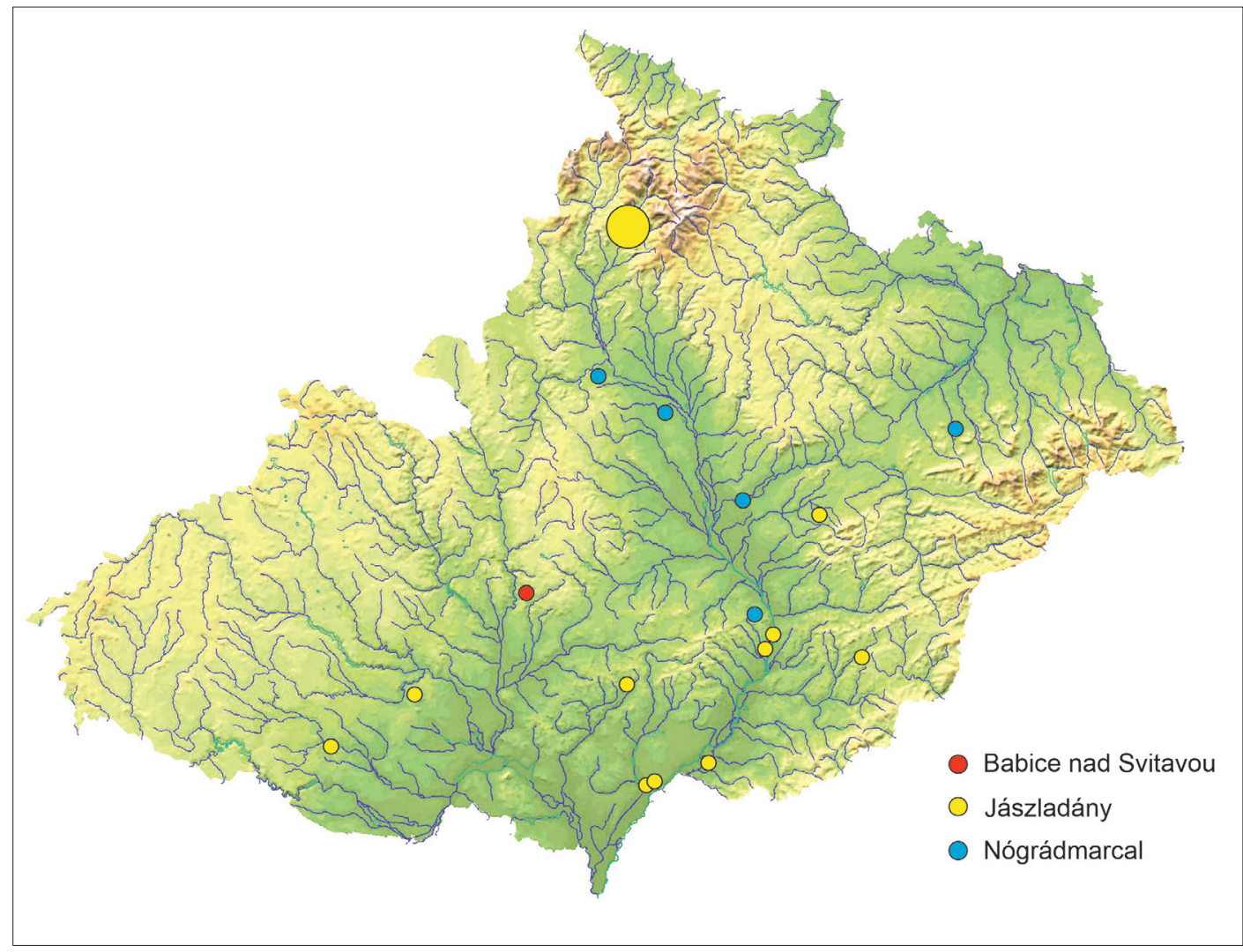

Obr. 7: Rozšî̌ení seker s křížovým ostř́m typu Jászladány a Nógradmarcal na Moravě a ve Slezsku. Mapa P. Grenar.

Fig. 7: Distribution of pickaxes of types Jászladány and Nógrádmarcal in Moravia and Silesia. Map P. Grenar.

a Praha-Liboc) a 3 lze zařadit k typu Nógrádmarcal (Dobeš 2013, 23-24). Epicentrem výskytu prvního typu je jednoznačně Karpatská kotlina (Vulpe 1975, 37-48; Patay 1984, 67-89), tedy oblast bodrogkeresztúrské kultury, kde i nálezy ze Zadunajska jsou považovány za importy (Patay 1984, 87-88; Dobeš 2013, 24). Analogické nálezy pocházejí z hrobů bodrogkeresztúrské kultury (Jászladány, Magyarhomorog-Kónyadomb, Rákoczifalva). Typ Nógrádmarcal je rozšíren zejména v severní části Karpatské kotliny a postupně slábnoucí nálezy jdou do středního Německa nebo až k Baltu (Dobeš et al. 2019, 30 se starší literaturou). V krystalizační oblasti jej nalezneme jakoby v okrajových partiích rozšíření dominantního typu Jászladány.

\subsection{Ražené znaky}

Po obvodu násadního otvoru se na vnitřní (spodní) straně nástroje nachází prstenec sotva znatelných vyražených 6 kruhových značek v pravidelných rozestupech (obr. 4-6). Takové a podobné znaky najdeme na mnoha exempláŕích, koncentrují se však pouze u některých typů sekeromlatů (Mezökeresztes, Székely-Nádudvár, Szendrő, Crestur, Agnița, Holíč, Handlová; ojediněle Vidra, Pločnik, Şiria, Mugeni, ) a seker $\mathrm{s}$ křížovým ostřím (všechny variety typu Jászladány, méně Nógrádmarcal, Kladari). Velmi časté jsou v Karpatské kotlině (Mad’arsko, Rumunsko, méně Slovensko), především v její severní a severozápadní části s jasně klesající 
frekvencí směrem k jihu (ojediněle Srbsko 2x, jinak nezdobené), na severozápad (obr. 9) a na východ (ojedinělý výskyt v Rumunsku vně Karpat). Jsou tedy totožné s rozšířením jednotlivých typů těžkých měděných artefaktů. Přitom poměr sekeromlatů a seker $\mathrm{s}$ krrížovým ostřím se znaky a bez nich je v zásadě v rovnováze (z celkového počtu ca do $20 \%$ : Heeb 2011, Fig. 68; 2014, Fig. 68). Tradičně jsou ražené znaky interpretovány jako dekorace nebo značky specifických výrobních dílen (Schubert 1965; Vulpe 1975; Patay 1984) a ani nejnovější studie zcela jednoznačnou interpretaci nepřinesla (Heeb 2011, 214). Podle některých autorů se znaky na typu Handlová vyvinuly z příbuzného typu Szendrő a jsou považovány za označení produkčních dílen (Schubert - Schubert 1999, 666), nebot produkty z mědi typu Handlová se územně se sekeromlaty eponymního typu kryjí, to však zjevně nebude platit u všech jmenovaných typů artefaktů nesoucí sledované znaky.

Ty mají v zásadě trojí podobu otisku/značky/kolku: prosté vtlačené kolečko, kolečko se zesíleným okrajem, kolečko se středovým výstupkem. U prvních dvou však neumíme přesně rozhodnout, zda jde o záměrné rozlišení nebo jen o sílu „ražby“. Znaky oscilují od sotva znatelných až po velmi výrazné (zejména typ Handlová). Uspořádání více méně odpovídá tomuto typu (Schubert - Schubert 1999, Abb. 8), někdy sestaveno po obvodu nebo do řad $s$ jasnou převahou alokace na vnitřní (spodní) straně v blízkosti násadního otvoru nebo na podélné ose předmětu. Nalezneme celou škálu kombinací znaků (Heeb 2011, 271-278; 2014, 88-94). Jen několik exemplářỏ nese znaky na vnější (svrchní) straně v blízkosti týlu (Patay 1984, Taf. 24: 267; Novotná 1970, Taf. 5: 99-101; Dobeš 2013, tab. 2: 3; 3: 1). Výjimečné jsou oboustranně shodné znaky (Vulpe 1975, Taf. 3: 33; 6: 48B; Patay 1984, Taf. 10: 167), někdy jsou znaky kruhové nahrazeny znaky půlměsícovitými nebo podkovovitými (Patay 1984, Taf. 14: 200) nebo vzácně obojí v kombinaci (Patay 1984, Taf. 19: 237; 41: 419). K dispozici jsou kombinace kruhových znaků a záseků (Patay 1984, Taf. 14: 199) nebo je celé schéma vytvořeno drobnými půlměsícovitými záseky (Vulpe 1975, Taf. 8: 61; Todorova 1981, Taf. 12: 165; 14: 173; Patay 1984, Taf. 15: 202; 25: 184; 37: 391).

$\mathrm{Na}$ Moravě je opatřeno sledovanými značkami jen několik exemplářů (obr. 8). Jedná se o sekeromlat typu Mezökeresztes z Moravičan, oba sekeromlaty typu Székely-Nádudvar z depotu ze Strážnice a ojedinělý nález z Rosic ( houský 1992, Taf. 1: 8; 2: 9, 10; Dobeš et al. 2019, obr. 2: 1-3; 10: 1-3). V Čechách máme k dispozici podobně jen 2 sekeromlaty typu Szendrő z Prahy-Strahova a z Vepřku a dva typu Székely-Nádudvar z Mlázovic a neznámé lokality v Čechách (Dobeš 2013, tab. 1: 3; 2: 3; 3: 1-2).

$\mathrm{Na}$ Slovensku se objevují na sekeromlatech typu Szendrő, Székely-Nádudvar, ale nejvýrazněji na typu Handlová s prstencem kolem násadního otvoru v obou formách (vtlačená kolečka a kolečka se středovým výstupkem: Novotná 1970, Taf. 4: 85, 91; 5: 100; 6: 102-103) i kombinace $\mathrm{s}$ výzdobou ostatních částí těla směrem k ostří (Novotná 1970, Taf. 5: 99, 101).

Bereme-li do úvahy jen vtlačené/ražené kruhové znaky (něco na způsob raženého kolku) ve smyslu značek výrobců, resp. producentských center (viz výše), a ponecháme-li stranou záseky, drážky a rýhy, které mohou představovat skutečnou výzdobu (cf. honosné kamenné sekeromlaty v salzmündské kultuře ve středním a SV Německu: Schunke 2013, Abb. 8; Jarecki - Moser 2014, Abb. 11: 4), měly by být splněny jisté předpoklady úvah ve smyslu správné interpretace: společné teritorium výskytu, omezená doba používání a shodný druh surovin. Největšího zastoupení dosahují znaky v severní, střední a SV části Karpatské kotliny (obr. 9) s minimálním vyzníváním směrem na $\mathrm{SZ}$ a $\mathrm{S}$. Jak přesvědčivě ukázala nejnovější analýza znaků (Heeb 2011, Fig. 77; 2014, Fig. 77), výskyt 

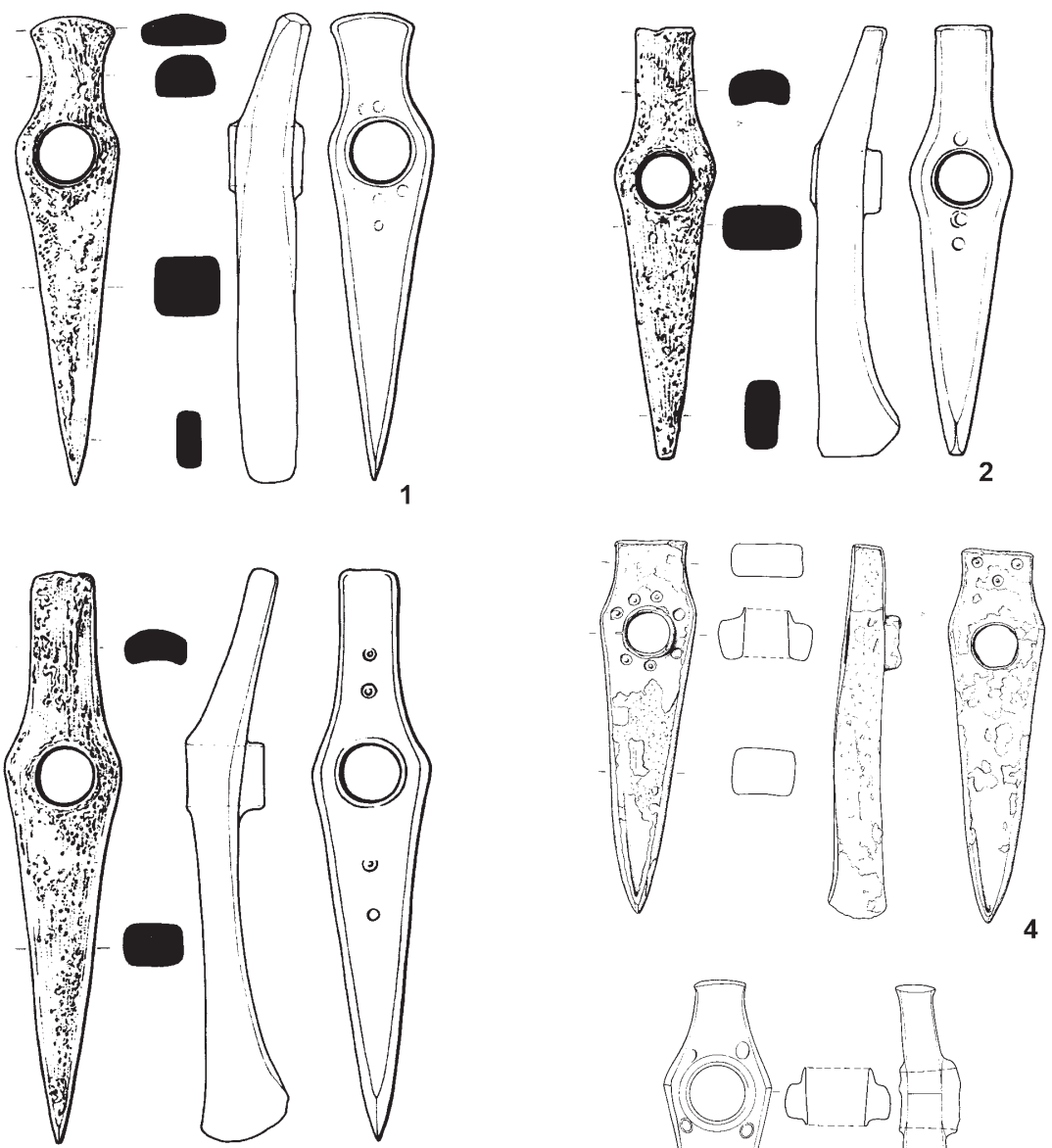

3
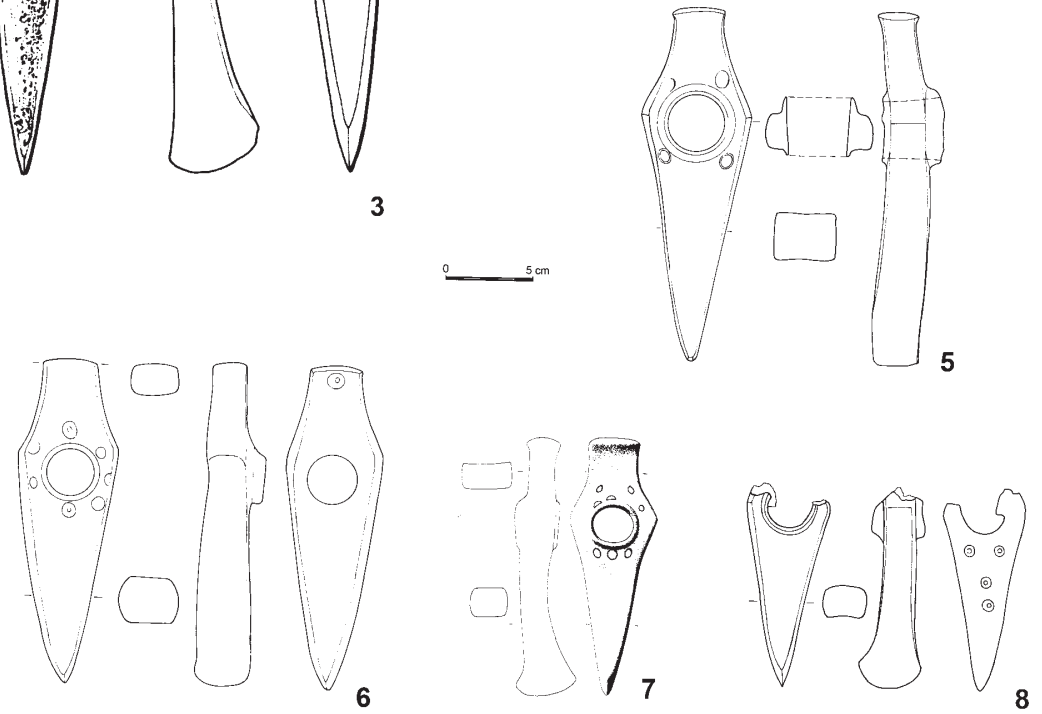

Obr. 8: Měděné sekeromlaty a sekery s křížovým ostřím opatřené raženými znaky na Moravě a v Čechách (podle Řihovský 1992; Dobeš et al. 2019; Dobeš 2013).

Fig. 8:Copper hammer-axes and pickaxes with embossed marks in Moravia and Bohemia (after Říhovský 1992; Dobeš et al. 2019; Dobeš 2013). 


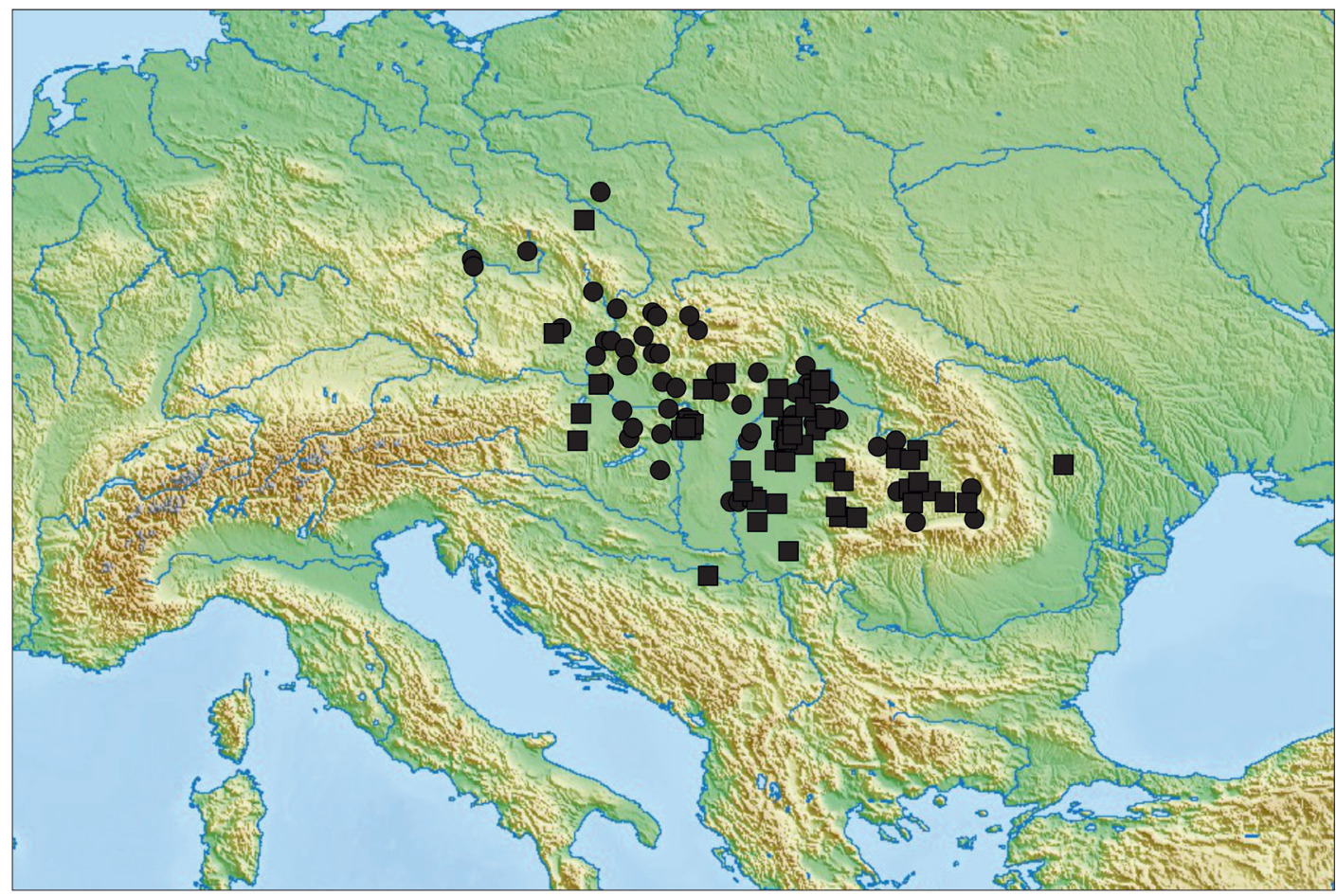

Obr. 9: Mapa výskytu těžké měděné industrie s raženými znaky v Karpatské kotlině a okolí. Mapa P. Grenar.

- - sekeromlaty typ Mezökeresztes, Székely-Nádudvar, Szendrö, Handlová, Crestur

- - sekery s křížovým ostřím typ Jászladány, Kladari, Nógrádmarcal, Vidra

Fig. 9: Distribution map of heavy copper artefacts with embossed marks in the Carpathian Basin and in its surroundings. Map P. Grenar.

- - x-type type Mezökeresztes, Székely-Nádudvar, Szendrö, Handlová, Crestur

- - axes with a cross blade type Jászladány, Kladari, Nógrádmarcal, Vidra

různých typů artefaktů se opakovaně vyskytuje přibližně na tomtéž teritoriu (již od dob práce E. Schuberta 1965 víme o koncentraci v Karpatské kotlině severně od Dunaje). Převážná část artefaktů je spojena s 2 . horizontem výskytu měděné industrie Balaton I - Ludanice - Jordanów - Bisamberg/Oberpullendorf - Brzéść Kujawski (Peška 2020), což v našich poměrech reprezentuje časný eneolit, přičemž nelze vyloučit o něco delší vyznívání, avšak zcela v minoritě. Splnění poslední podmínky - typ suroviny - to je otázka obtížně řešitelná, nebot kdyby se mělo jednat o značky produkčních dílen, musely by být artefakty vyrobeny ze stejného druhu mědi pro tu kterou kompaktní oblast, což je těžké dosavadními analýzami doložit.

Znaky jsou nejen rozdílného typu, ale také nestejné velikosti, tvaru a hloubky, občas jsou ve vzájemné „superpozici“ (čili přerážené částečně přes sebe). Vše působí dojmem použití různých razidel a možná také $\mathrm{v}$ různé době (předpokládáme razidla již do studeného kovu, avšak exaktní zjištění by znamenalo destruktivní analýzu - výřez, což jsme nechtěli dopustit).

Označení váhových kategorií předpokládá v zásadě jednotnou nebo pravidelně odstupňovanou škálu u jednoho typu, což zjevně neplatí, nebơ v rámci jednotlivých typů hmotnost ko- 


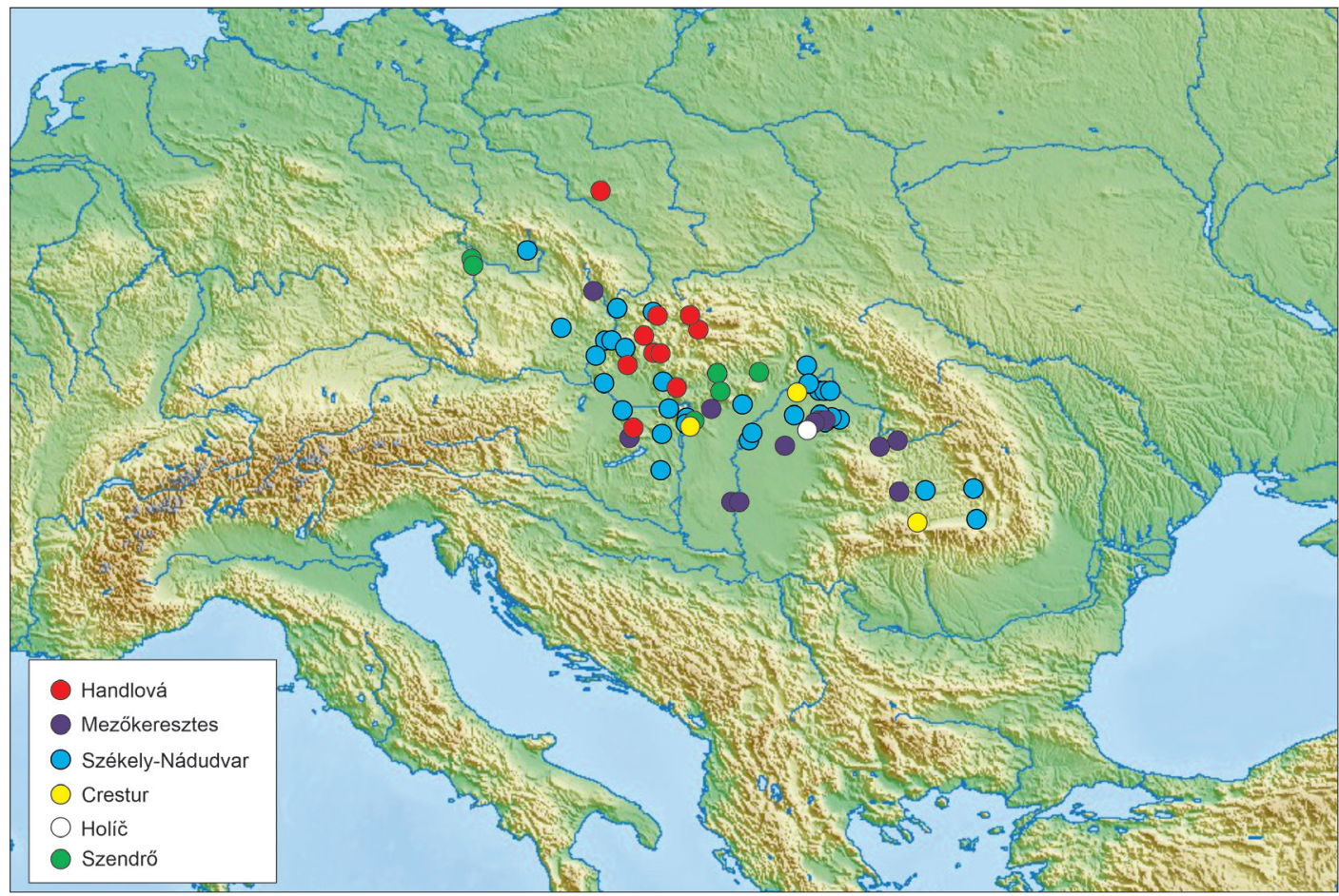

Obr. 10: Mapa výskytu sekeromlatů z časného eneolitu s raženými znaky v Karpatské kotlině a okolí. Mapa P. Grenar.

Fig. 10: Distribution map of Early Eneolithic hammer-axes with embossed marks in the Carpathian Basin and in its surroundings. Map P. Grenar.

lísá, a to ve většině případů dost podstatným způsobem (obr. 12-18). Celkem evidujeme přes 170 artefaktů s vyraženými znaky, mezi sekeromlaty je nejčastěji zastoupen typ Székely-Nádudvar a mezi sekerami s křížovým ostřím typ Jászladány (obr. 10, 11).

Např. i u tak vyhraněného zástupce, jakým je územně a časově omezený sekeromlat typu Handlová, najdeme značný rozptyl hmotnosti (1055 - $3240 \mathrm{~g})$, ale nakonec i počet a umístění znaků. Znaky jsou bohatě opatřeny skoro všechny exempláře a tento „dekor“ patří fakticky k charakteristikám typu, dosahujíce počtu mezi 7 až 18 znaky (obr. 13).

Např. daleko menší počet (nejčastěji $1+1$ u násady) je příznačný pro sekery s kř́ižovým ostř́im typu Jászladány (všechny varianty). Pod- mínky interpretace ve smyslu značek producentských dílen by tak byly de facto splněny. Úvahu o označení producenta však oslabuje fakt, že jiné kategorie zjevně současné měděné industrie (ploché sekery, dláta, dýky) takové znaky vůbec nenesou. Zcela mimo úvahy tak možná není ani označení jisté míry prestiže (společenské, symbolické?) nebo obchodovatelnosti artefaktu rostoucí úměrně s počtem znaků (a jejich alokací?), plnící částečně funkci výzdoby a částečně oné hodnoty, kdy příklady (snad) „přeražby“ nebo znaky působící různorodým dojmem by mohly hodnotu artefaktu uměle navyšovat (někdo si k původní hodnotě „přirazil“"?). To vše bez exaktního dokladu smyslu ražených znaků zůstává prozatím v rovině úvah a hypotéz. 


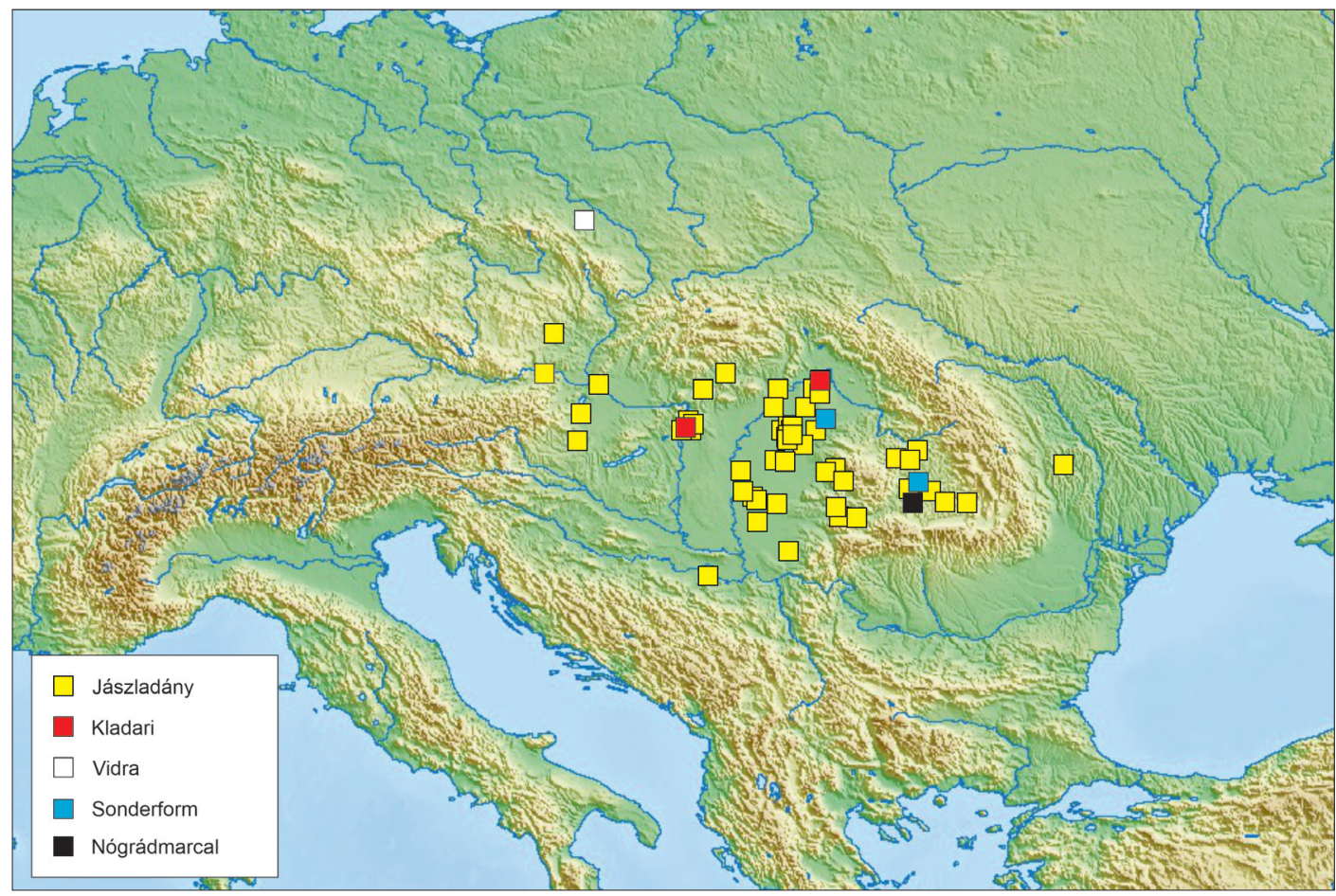

Obr. 11: Mapa výskytu seker s křížovým ostřím z časného eneolitu s raženými znaky v Karpatské kotlině a okolí. Mapa P. Grenar.

Fig. 11: Distribution map of Early Eneolithic pickaxes with embossed marks in the Carpathian Basin and in its surroundings. Map P. Grenar.

\subsection{Datování}

Na základě výskytu v hrobech bodrogkeresztúrské kultury v Mad’arsku od přechodu mezi kulturou tiszapolgárskou a bodrogkeresztúrskou až po Bodrogkeresztúr B (a odpovídající datování v Cucuteni AB) lze v našich poměrech synchronizovat výskyt těchto seker $\mathrm{s}$ křížovým ostřím $\mathrm{s}$ jordanovskou kulturou, resp. s horizontem (2.) výskytu měděné industrie Balaton I - Ludanice - Jordanów - Bisamberg/Oberpullendorf - Brzéść Kujawski (Peška 2020). Do stejného časového horizontu náleží i typ Nógrádmarcal, o čemž nejlépe vypovídá společný výskyt v již zmíněném depotu z Roudnice (Dobeš 2013, 2122, tab. 4: 2-3). Problémem je v této souvislosti přesná datace depotu z Malých Levár (Novotná 1970, 14, 25, Taf. 1: 2; 7: 125 a 48B), kde se kro- mě typu Nógrádmarcal objevuje ještě dýka typu Malé Leváre a část velkého brýlovitého závěsku s očkem stejnojmenného typu, to vše v doprovodu ploché sekery typu Altheim (archaický exemplář). Zatímco ostatní artefakty jsme schopni bez větších obtíží synchronizovat s počátky eneolitu, prrítomnost sekery typu Altheim je obvykle spojována až s následným postjordanovským obdobím (Balaton II/III - Bajč-Retz-Křepice Mondsee - Baalberg - mladší Michelsberg), což v některých oblastech znamená brázděný vpich a počátky nálevkovitých pohárů. I když je zde náznak přežívání dýk typu Malé Leváre až do doby Cucuteni B (Novotná 1982, 316), u brýlovitých závěsků bychom měli být opatrní, nebot argumentovaný závěsek z depotu v Hlinsku je jiného typu (Jordanów) a př́́kladem jeho přežívání je zatím právě jen depot z Hlinska (Pavelčrik 


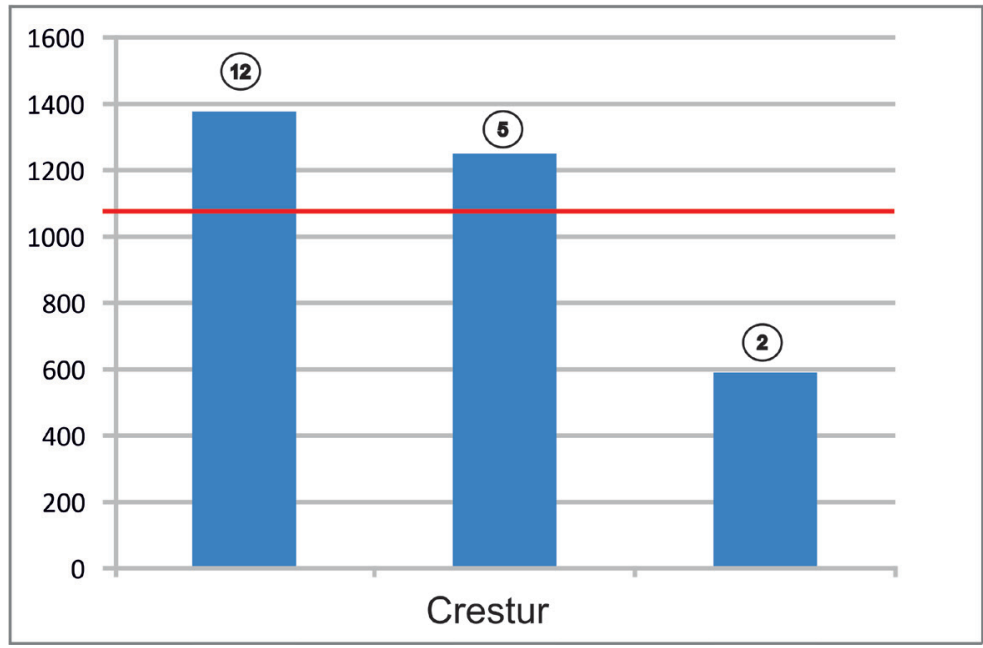

Obr. 12: Sekeromlat typu Crestur. Graf hmotností exemplářu s počtem ražených znaků (v kolečku), průměrnou hmotnost symbolizuje červená linie. Graf P. Grenar.

Fig. 12: Hammer-axe of type Crestur. Weight graph of specimens with numbers of embossed marks (in circle), average weight is represented by red line. Graph P. Grenar.

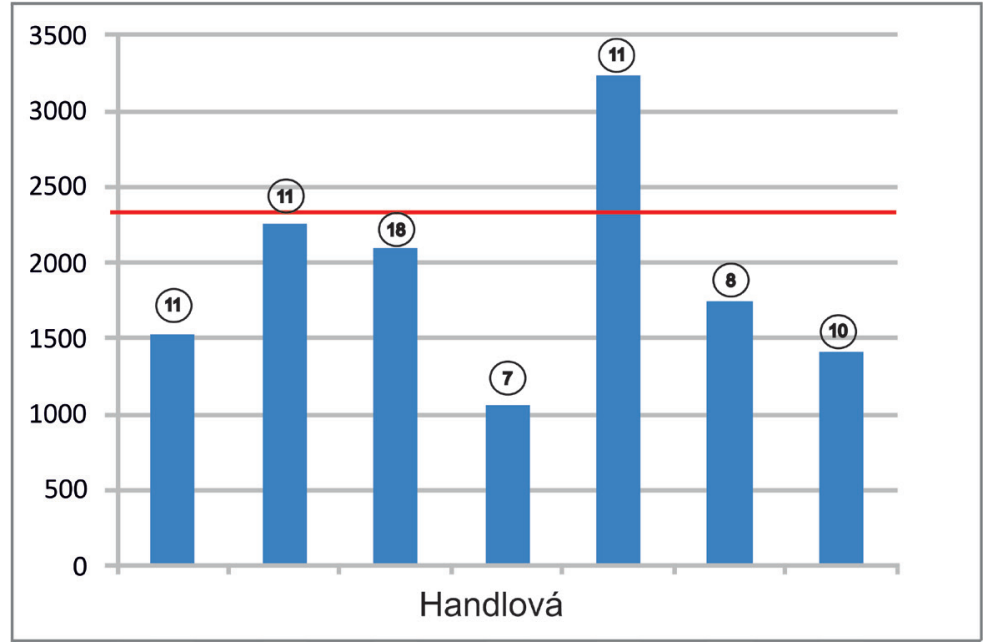

Obr. 13: Sekeromlat typu Handlová. Graf hmotností exemplářu s počtem ražených znaků (v kolečku), průměrnou hmotnost symbolizuje červená linie. Graf P. Grenar.

Fig. 13: Hammer-axe of type Handlová. Weight graph of specimens with numbers of embossed marks (in circle), average weight is represented by red line. Graph P. Grenar. 


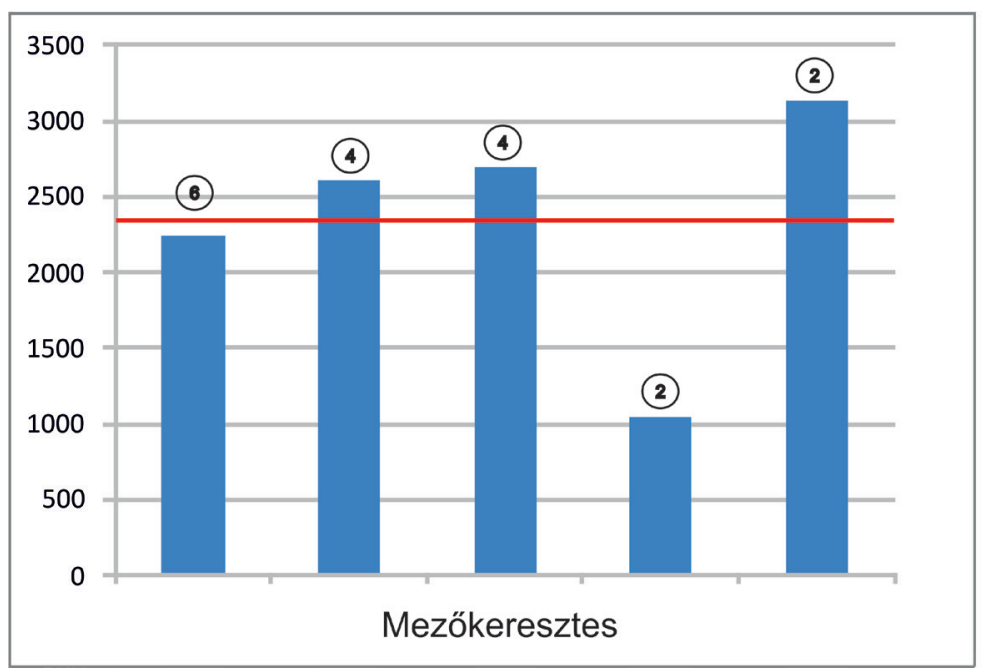

Obr. 14: Sekeromlat typu Mezökeresztes. Graf hmotností exemplářů s počtem ražených znaků (v kolečku), průměrnou hmotnost symbolizuje červená linie. Graf P. Grenar.

Fig. 14: Hammer-axe of type Mezőkeresztes. Weight graph of specimens with numbers of embossed marks (in circle), average weight is represented by red line. Graph P. Grenar.

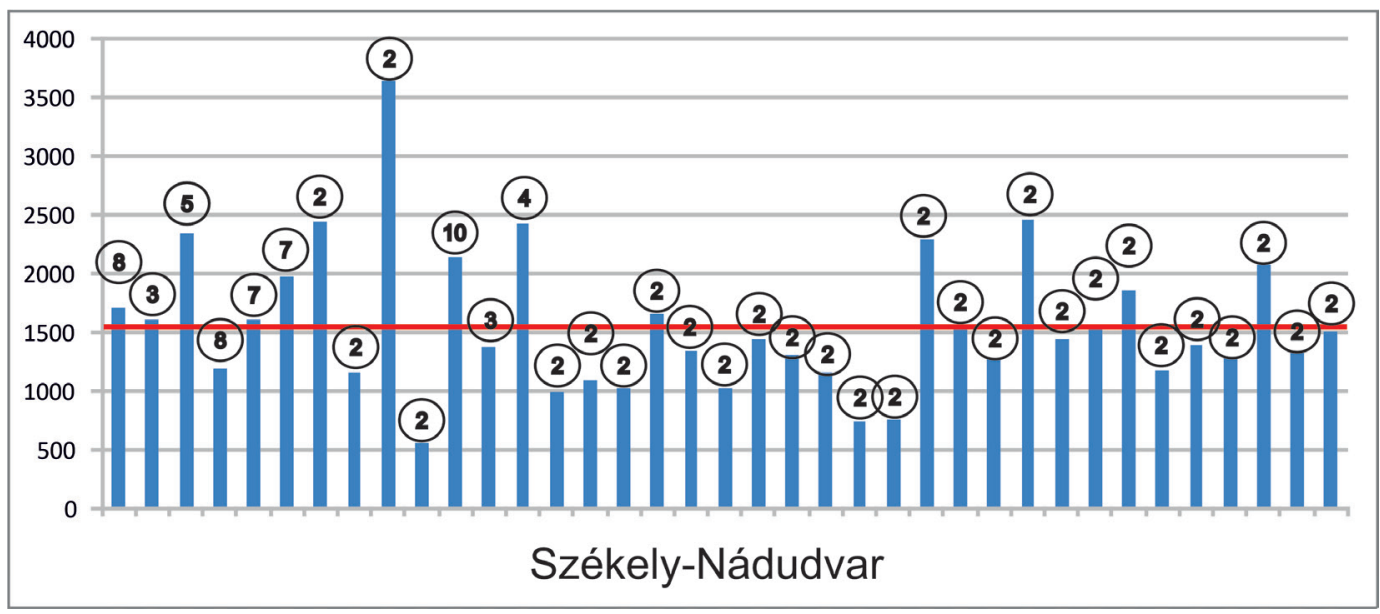

Obr. 15: Sekeromlat typu Székely-Nádudvar. Graf hmotností exemplářů s počtem ražených znaků (v kolečku), průměrnou hmotnost symbolizuje červená linie. Graf P. Grenar.

Fig. 15: Hammer-axe of type Székely-Nádudvar. Weight graph of specimens with numbers of embossed marks (in circle), average weight is represented by red line. Graph P. Grenar. 


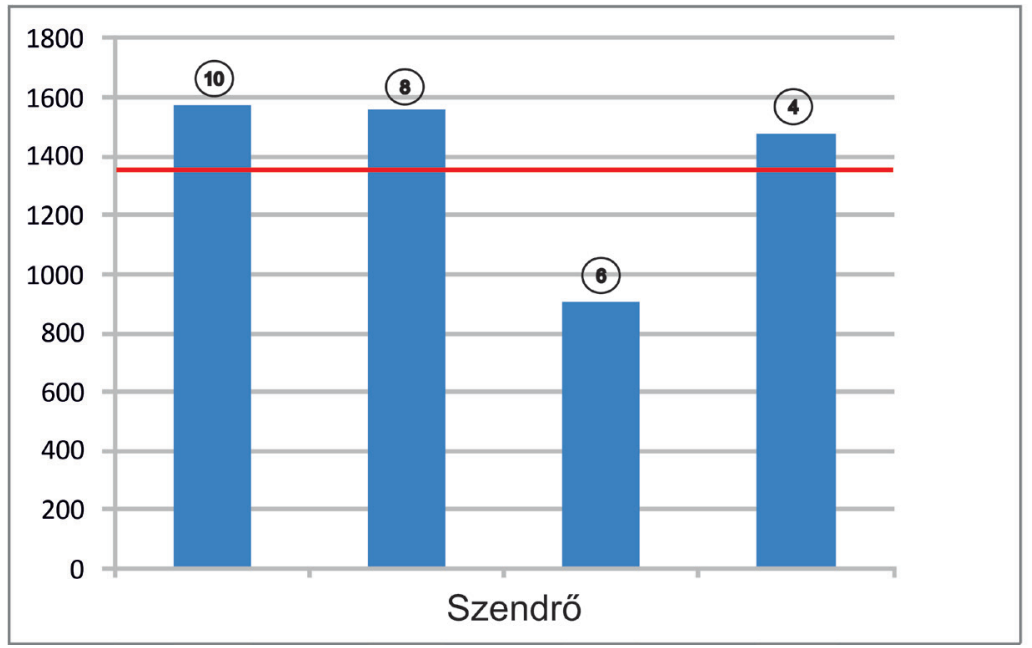

Obr. 16: Sekeromlat typu Szendrő. Graf hmotností exemplářů s počtem ražených znaků (v kolečku), průměrnou hmotnost symbolizuje červená linie. Graf P. Grenar.

Fig. 16: Hammer-axe of type Szendrő. Weight graph of specimens with numbers of embossed marks (in circle), average weight is represented by red line. Graph P. Grenar.

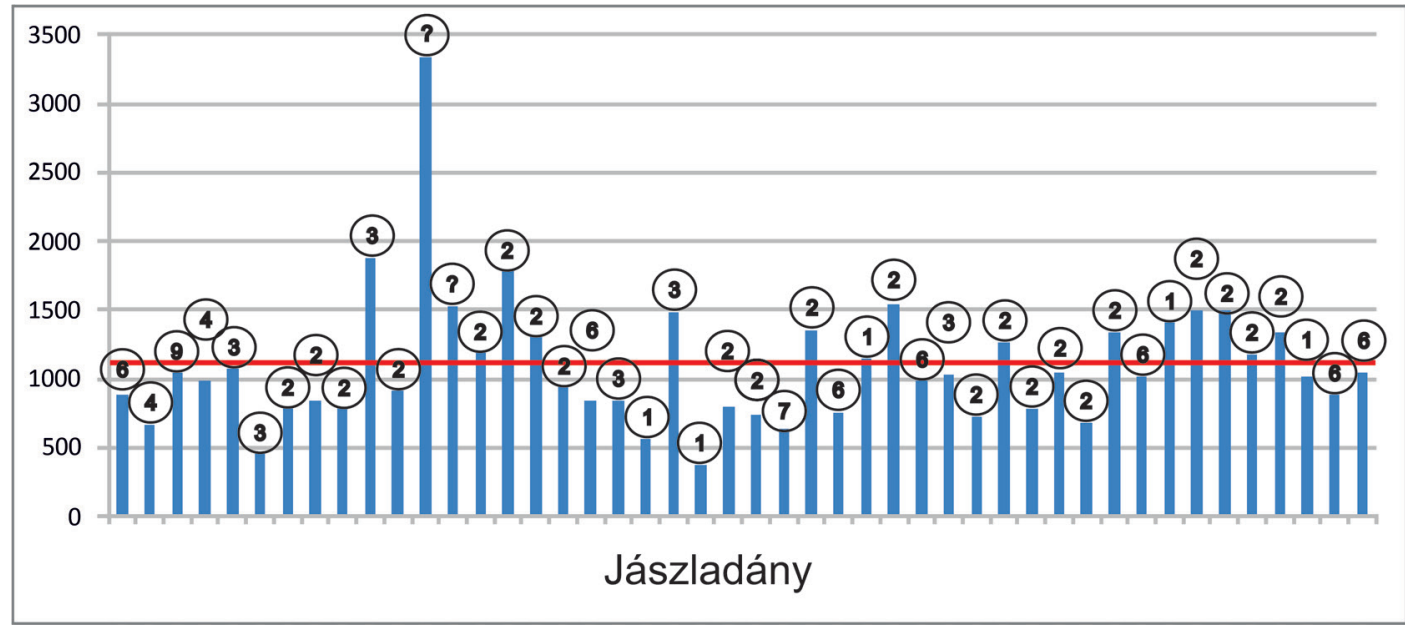

Obr. 17: Sekera s křižovým ostřím typu Jászladány. Graf hmotností exemplářu s počtem ražených znaků ( $v$ kolečku), průměrnou hmotnost symbolizuje červená linie. Graf P. Grenar.

Fig. 17: Pickaxe of type Jászladány. Weight graph of specimens with numbers of embossed marks (in circle), average weight is represented by red line. Graph P. Grenar. 


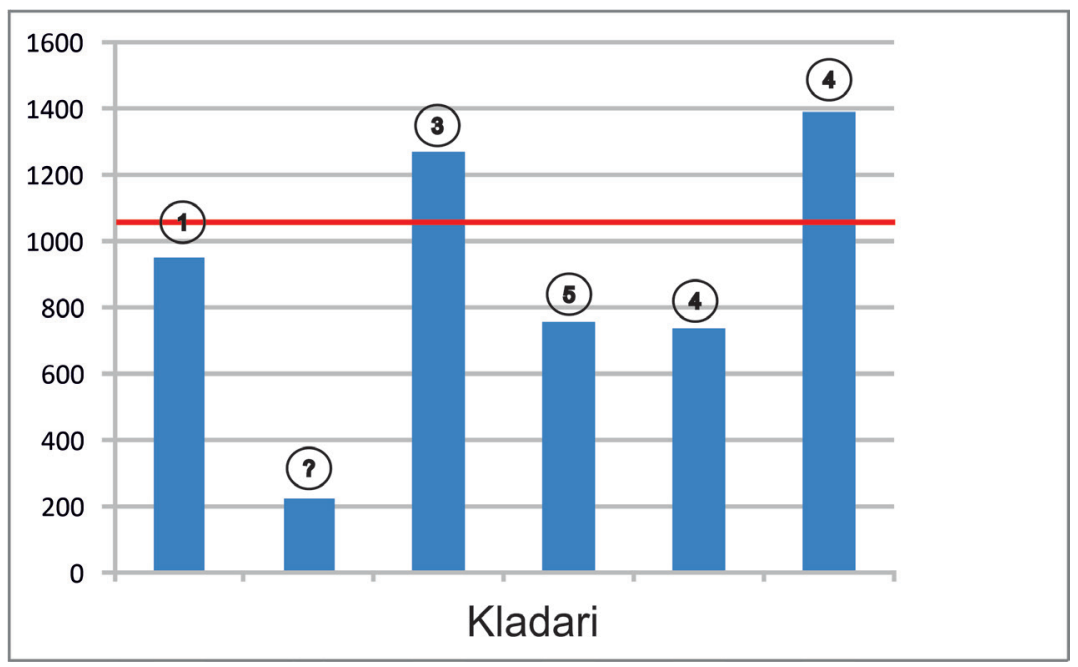

Obr. 18: Sekera s křížovým ostřím typu Kladari. Graf hmotností exemplářů s počtem ražených znaků (v kolečku), průměrnou hmotnost symbolizuje červená linie. Graf P. Grenar.

Fig. 18: Pickaxe of type Kladari. Weight graph of specimens with numbers of embossed marks (in circle), average weight is represented by red line. Graph P. Grenar.

1979, 331), i když je zřejmé, že typ (tento nebo jiný?) drobných brýlovitých závěsků pokračuje dál až do doby bronzové. Časnější nástup seker typu Altheim by měl být navíc podepřen její přítomností ve svrchní vrstvě sídliště s keramikou brázděného vpichu ve Vrádišti (Dobeš 2013, 24). To jsou současně nepřímé argumenty pro pozdější vyznění seker s křížovým ostřím typu Nógrádmarcal, které by však nutně musely platit i pro dýky typu Malé Leváre a masivní brýlovité závěsky s háčkem stejnojmenného typu. Zda shodné přeživání platí také pro typ Jászladány, nelze bez podnětných nových nálezů říct.

\section{Metalografická analýza, původ kovu}

Analýza byla provedena ručním rentgenflurorescenčním spektrometrem pXRF, přístroj Delta Dynamic (Olympus, USA, Waltham, MA), doba analýzy $300 \mathrm{~s}$, 1. fáze 1-40 KV, Rh anoda (měření Mgr. K. Jagošová, ACO) a podobnou metodikou (XRF) na Technische Universität Bergakademie Freiberg Institut für Archäometallurgie (A. Langer). Výsledkem je zjištění, že sekera s křížovým ostřím z Babic nad Svitavou byla vyrobena z čisté mědi se stopovým zastoupením stř́bra a niklu (obr. 19) a u analýzy A. Langera (2002) je v případě vzorku z násadního otvoru zaznamenán nárůst podílu stříbra, jinak je analýza shodná. To ji spojuje s ostatními moravskými artefakty téhož typu (obr. 20), kde se u několika artefaktů objevuje znečištění arzénem, avšak ne v takovém objemu, aby bylo možno uvažovat o jiném typu mědi. Jistá skupina nálezů (Hodonín, Napajedla, Velké Losiny) vykazuje nízkým zastoupením antimonu určité znaky mědi typu Nógrádmarcal, z níž je zhotovena např. sekera s kř́ižovým ostřím typu Nógrádmarcal ze sídlištního objektu v Dluhonicích 2 (obr. 19, 20). Oba typy artefaktů by měly být shodného stáří (viz výše).

Oba typy čisté mědi ( $\mathrm{N}$ a E00) se odlišují jen nepatrně a jejich distribuce není omezena jen na počáteční stadium metalurgizace a aplikuje 


\begin{tabular}{|c|c|c|c|c|c|c|c|c|c|c|c|}
\hline & $\mathrm{Cu}$ & As & $\mathrm{Ag}$ & $\mathrm{Sb}$ & $\mathrm{Bi}$ & $\mathrm{Pb}$ & Co & $\mathrm{Au}$ & Sn & $\mathrm{Fe}$ & $\mathrm{Ni}$ \\
\hline \multirow{2}{*}{$\begin{array}{l}\text { Sekera s kř́ízovým ostřím } \\
\text { Babice nad Svitavou }\end{array}$} & & & & & & & & & & & 0,01 \\
\hline & 99,89 & $<L O D$ & 0,01 & $<L O D$ & $<L O D$ & $<L O D$ & $<L O D$ & $<L O D$ & $<L O D$ & $<L O D$ & 0,01 \\
\hline \multirow{2}{*}{$\begin{array}{l}\text { Sekera s křížovým ostřím } \\
\text { Dluhonice } 2\end{array}$} & & & 0,22 & 0,44 & 0,15 & $<L O D$ & $<L O D$ & $<\mathrm{LOD}$ & $<L O D$ & $<\mathrm{LOD}$ & $<\mathrm{LOD}$ \\
\hline & 99,00 & $<\mathrm{LOD}$ & 0,21 & 0,40 & 0,15 & $<L O D$ & $<L O D$ & $<\mathrm{LOD}$ & $<L O D$ & $<\mathrm{LOD}$ & $<L O D$ \\
\hline
\end{tabular}

Obr. 19: Výsledky pXRF analýzy dvou seker s křížovým ostřím (typ Jászladány Babice nad Svitavou; typ Nógrádmarcal Přerov - Dluhonice 2). Měření K. Jagošová.

Fig. 19: Results of pXRF analysis of two pickaxes (type Jászladány from Babice nad Svitavou; type Nógrádmarcal from Přerov - Dluhonice 2). Measurement K. Jagošová.

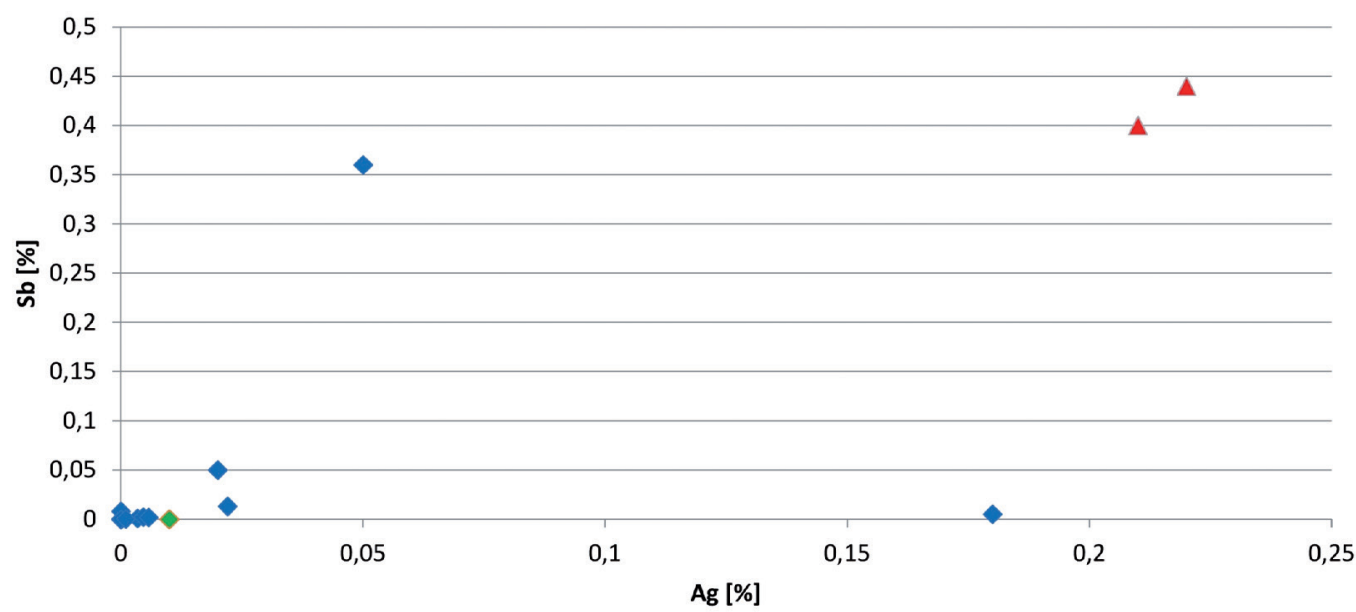

- Jászladány $\quad$ Jászladán Babice nad Svitavou $\quad \Delta$ Nògrádmarcal Dluhonice 2

Obr. 20: Srovnávací diagram zastoupení stopových prvků stříbra a antimonu u seker s křížovým ostř́m typu Jászladány a Nógrádmarcal. Sestavila K. Jagošová.

Fig. 20: Comparative diagram of the representation of trace elements silver and antimony in pickaxes of types Jászladány and Nógrádmarcal. Created by K. Jagošová.

se i u jiných artefaktů až do pozdního eneolitu (kultura zvoncovitých pohárů). At̉ už z ryzího kovu nebo $\mathrm{z}$ rud se $\mathrm{s}$ čistou mědí setkáváme prakticky v celé Evropě a je obtížné stanovit její provenienci. S ohledem na masový výskyt seker typu Jászladány v Sedmihradsku a v Potisí se uvažuje o jižní části Karpatského bazénu (Patay 1984, 10), ale v úvahu teoreticky přichází vlastně všechny výchozy měděných rud, výjimkou je střední Slovensko, produkující měd' s antimonem, arzénem etc. (Dobeš et al. 2019, 35).
Antimonová měd' typu Nógrádmarcal byla oblíbená v jordanovském horizontu zejména na severním okraji Karpatské kotliny, západně od Bukových hor a západně od Karpat v Čechách, středním Německu a ojediněle i v Dánsku. Současný stav poznání připouští slovenské zdroje (Západní a Starohorské Nízké Tatry) s více doklady pravěké těžby, ovšem relativizovaných z důvodu značného překryvu výsledků kovu z dalších rudonosných oblastí (naposled Dobeš et al. 2019, 35-36). 


\section{Význam a funkce}

Měděná sekera s křížovým ostřím typu Jászladány z Babic nad Svitavou patří jednoznačně do skupiny časně eneolitických těžkých předmětů (Schwergerät) společně se sekeromlaty a 1. skupinou plochých seker. Na našem artefaktu nenacházíme žádné stopy praktického používání, což je pro část těchto předmětů typické, na rozdíl od jiných kusů, na nichž jsou pozorovatelné stopy dlouhodobého používání ve formě ztupeného ostří, rozšířeného týlu se stopami po úderech nebo jasné stopy poškození interpretovatelné jako nástroje nebo zbraně. $\mathrm{V}$ našem prostředí postrádáme přímé doklady jejich výroby, $\mathrm{k}$ dispozici jsou pouze první početnější doklady kovovýroby obecně (Peška 2020). Většina autorů se ztotožňuje s jejich funkcí spíše $\mathrm{v}$ rovině ceremoniální a ideové, jako odznak a symbol moci a určitého společenského postavení, deklarující mimo jiné i vůdčí pozici mužů (hrobové nálezy). Nevylučujeme však ani roli směny prestižního zboží. Měkká měd' a mnohdy značná hmotnost vysoce kontrastují s praktickým používáním např. při zpracování dřeva etc. Proti funkci ingotů nebo směnného ekvivalentu hovoří pečlivost jejich výroby a úpravy, stejně jako značně kolísající hmotnost jednotlivých kusů v rámci jednoho typu (obr. 12-18), která by se při plnění obou funkcí dala předpokládat. Funkce prestižního a reprezentativního odznaku moci a společenské pozice spolu s výměnou luxusního zboží tak zůstávají nejpravděpodobnějším funkčním modelem těchto artefaktů (nebo jejich převážné většiny). $\mathrm{S}$ takovou reprezentativní funkcí nebo směnou může nakonec jistým způsobem souviset i jejich „výzdoba“ v podobě ražených znaků.

\section{Závěr}

Ojedinělý nález (nebo monodepozitum) měděné sekery s kř́ižovým ostřím typu Jászladány s jistými znaky typu Nógrádmarcal z lokality na území Moravského krasu rozšiřuje dosavadní sérii těchto artefaktů na Moravě a výrazně obohacuje nálezový fond tohoto regionu. Největší koncentraci výskytu sledovaného typu zaznamenáváme v Karpatské kotlině na území bodrogkeresztúrské kultury, kde i zadunajské nálezy jsou považovány za importy. Pozoruhodný je prstenec šesti špatně čitelných ražených kruhových značek kolem násadního otvoru na spodní straně předmětu (obr. 4-6). Shodné znaky nacházíme na více typech sekeromlatů a seker s křrižovým ostřím soustředěných opět na území Karpatské kotliny (Mad'arsko, Rumunsko, méně Slovensko) v její severní a severozápadní části. Znaky jsou tradičně interpretovány jako dekor nebo značky výrobních dílen, resp. producentských center, pro což je splněna většina podmínek (shodné teritorium výskytu, omezená doba používání, shodný typ suroviny - zde nejednoznačné). Díky charakteru znaků (různé typy, hloubka, superpozice) nelze vyloučit použití více razidel. Úvaze o označování jednotlivých např. váhových kategorií brání značně kolísající hmotnost, a to i rámci jednoho typu (obr. 12-18), označení producentských dílen zase skutečnost, že jiné současné měděné industrie (ploché sekery, dláta, dýky) žádné znaky/ značky nenesou. Do popředí se dostává možnost označení jisté míry prestiže (společenské, symbolické) nebo obchodovatelnosti artefaktu rostoucí úměrně s počtem znaků (přeražby by pak mohly být svědectvím umělého navýšení hodnoty předmětu) a podtrhujícího prestižní a mocenskou hodnotu artefaktu. Sekeru s křížovým ostřím z Babic lze v našem prostředí velice dobře datovat do doby jordanovské kultury a přiřadit ke 2 . horizontu výskytu měděné industrie na Moravě. Surovina použitá k výrobě 
babické sekery (čistá měd' se stopami stříbra a niklu) připouští zdroje $\mathrm{v}$ karpatské oblasti (Sedmihradsko?), přitom vylučuje střední Slovensko (zde antimonová měd' typu Nógrádmarcal), avšak jednoznačný výsledek k dispozici nemáme.
Ojedinělý př́iklad zástupce této prestižní a reprezentativní kategorie mocenského a společenského postavení muže z prostředí Moravského krasu, na eneolitické kovy dosud velice skoupého regionu, je výrazným příspěvkem do prehistorie této zvláštní sídelní jednotky na počátku eneolitu.

Předložená studie vznikla za finančni podpory Ministerstva kultury v rámci institucionálního financování na dlouhodobý koncepčni rozvoj výzkumné organizace Moravské zemské muzeum (DKRVO, MK000094862).

\section{Bibliografie}

Antonović, D. 2014: Kupferzeitliche Äxte und Beile in Serbien. Prähistorische Bronzefunde IX/27. Stuttgart.

Boroffka, N. 2009: Simple Technology. Casting Moulds for Axe-adzes. In: T. L. Kienlien, T. L. Roberts, B. W. (eds.): Metals and societies. Studies in honour of Barbara S. Ottaway. Bonn, 246-257.

Dobeš, M. 2013: Měd' v eneolitických Čechách. Dessertationes archaeologicae Brunenses/Pragensesque 16. Praha.

Dobeš, M. - Fikrle, M. - Drechsler, A. - Faltýnek, K. Fojtik, P. - Halama, J. - Jarůšková, Z. - Kalábek, M. - Langová, J. - Schenk, Z. - Španihel, S. - Pě̌ka, J. 2019: Eneolitická měděná industrie na Moravě. Nové a staronové nálezy ve světle stávajících poznatků o vývoji středoevropské metalurgie, $\mathrm{Pa}-$ mátky archeologické CX, 5-58.

Driehaus, J. 1952: Zur datierung und Herkunft donauländischen Axttypen der frühen Kupferzeit, Archaeologia Geographica 3, 1-8.

Halama, J. 2015: Další měděná sekera s křížovým ostřeím z Velkých Losin (okr. Šumperk) - mohlo jít o eneolitický depot z podhůří Jeseníků? Pravěk NŘ 23, 5-16.

Heeb, J. 2011: Copper shaft-hole axes and early metallurgy in south-eastern Europe: an integrated approach. Thesis fot the degrese of Doctor of Philosophy in Archaeology, University of Exeter, pdf verze.

Heeb, J. 2014: Copper Shaft-Hole Axes and Early Metallurgy in South-Eastern Europe. Oxford.
Chvojka, O. - Jiráň, L. - Metlička, M. a kolektiv 2017: Nové české depoty doba bronzové. Hromadné nálezy kovových předmětů učiněné do roku 2013. České Budějovice - Praha - Plzeň.

Jarecki, H. - Moser, A. 2014: Zur Erforschung der Salzmünder Kultur. In: Meller, H. - Friederich, S. (Hrsg.), Salzmünde-Schiepzig - ein Ort, zwei Kulturen. Ausgrabungen an der Westumfahrung Halle (A 143) Teil I, Archäologie in Sachsen-Anhalt, Sonderband 21/I, Halle (Saale), 211-222.

Jiráň, L. 2008: Archeologie pravěkých Čech 5. Doba bronzová. Praha.

Langer, A. 2002: Metallographische und analytische Untersuchungen an einer kreuzschneidigen Axt und ihrem Nachguss. Studienarbeit Technische Universität Bergakademie Freiberg Institut für Archäometallurgie. Rukopis práce, archiv AÚ MZM, Brno.

Novotná, M. 1955: Medené nástroje v Čechách a na Morave, Archeologické rozhledy VII, 510-517.

Novotná, M. 1970: Die Äxte und Beile un der Slowakei. Prähistorische Bronzefunde IX/3. München.

Novotná, M. 1982: Zur Stellung einiger Kupferdolchen am mittleren Donau. In: Todorova, H. (ed.), Thracia praehistorica. Supplementum Pulpudeva 3. Semaines philippopolitaines de L'histoire et de la culture thrace. Plovdiv 4-19 octobre 1978. Sofia, 311-319.

Pavelč́k, J. 1979: Depot měděných šperků z Hlinska u Lipníku nad Bečvou, Památky archeologické LXX, 319-339. 
Patay, P. 1984: Kupferzeitliche Meißel, Beile und Äxte in Ungarn. Prähistorische Bronzefunde IX/15. München.

Peška, J. 2020: Nejstarší kovová industrie Moravy. In: Cheben, I. - Kalábková, P. - Metlička, M. (eds.), Sborník z konferencí neolit/eneolit našich zemí 2017-2019, Archaeologica Slovaca Monographiae, Nitra: Archeologický ústav SAV; Olomouc: Univerzita Palackého v Olomouci; Plzeň: Západočeské muzeum v Plzni, 2020, 161-190.

Řihovský, J. 1992: Die Äxte, Beile, Meißel znd Hämmer in Mähren. Prähistorische Bronzefunde IX/117. Stuttgart.

Salaš, M. 2005: Bronzové depoty střední až pozdní doby bronzové na Moravě a ve Slezsku. Brno.

Schubert, F. 1965: Zu den südosteuropäischen Kupferäxten, Germania 43, 274-295.
Schubert, E. - Schubert, F. 1999: Die Hammeräxte vom Typus Handlová. In: Herrmann, F. R. (Hrsg.), Festschrift für Günter Smolla II. Materialien zur Vor- und Frühgeschichte in Hessen 8, Wiesbaden, 657-671.

Schunke, T. 2013: Die Salzmünde Kultur - eine aussergewöhnliche Steinzeitkultur in Mitteleuropa. In: Meller, H. (Hrsg.), 3300 BC. Mysteriöse Steinzeittote und ihre Welt. Halle (Saale), 246-256.

Šikulová, V. - Zápotocký, M. 2010: Raně eneolitický měděný pektorál z vrchu Kotouče u Štramberka, Archeologické rozhledy LXII, 395-428.

Todorova, H. 1981: Die kupferzeitlichen Äxte und Beile in Bulgarien. Prähistorische Bronzefunde IX/14. München.

Vulpe, A. 1975: Die Äxte und Beile in Rumänien II. Prähistorische Bronzefunde IX/55. München. 


\section{Finding of the early Eneolithic so-called heavy copper industry from the Moravian Karst in the Blansko region}

The isolated find (or mono-deposit) of a copper pickaxe of type Jászladány with some attributes of the Nógrádmarcal type from a site in the territory of the Moravian Karst extends the previously known series of these artefacts in Moravia and distinctly enriches the spectrum of finds from this region. The largest concentration of this type of axes is known from the Carpathian Basin, more precisely from the territory of Bodrogkeresztúr Culture, where Transdanubian finds are regarded as imports. Remarkable is a ring of six badly readable embossed circular marks around the shaft hole on the bottom side of the object (Figs. 4-6). Identical marks are also found on other types of hammer-axes and pickaxes which are concentrated in the northern and north-western parts of the Carpathian Basin (Hungary, Romania, to a lesser extent Slovakia). The symbols are traditionally interpreted as decorative elements or as brands of workshops or production centres. The most conditions would speak for the latter theory (identical distribution territory, limited period of use, the same type of raw material - here uncertain). The character of symbols (various types, depth, superposition) might indicate that multiple dies were used. The theory of markings referring e.g. to individual weight categories is contradicted by the very variable weight, even within the same type (Fig. 12-18).
The idea of production workshop brands is doubted by the fact that other contemporaneous copper artefacts (flat axes, chisels, daggers) do not bear any symbols/marks. An issue being discussed is the possibility of marking certain degree of prestige (social, symbolical) or tradability of an artefact, which increased together with the rising number of symbols (re-embossing might indicate an artificial increase in the artefact's value) and accentuated the prestige and power value of the artefact. In our milieu, the pickaxe from Babice can be very well dated to the period of Jordanów Culture and it can be classed with the 2nd horizon of copper industry in Moravia. The raw material used to make the pickaxe from Babice (pure copper with traces of silver and nickel) might refer to sources in the Carpathian region (Transylvania?), at the same time excluding Middle Slovakia (occurrence of antimony copper of type Nógrádmarcal). However, any definite result is not yet known.

The isolated example of this prestigious and representative category of power and social status of men from the territory of the Moravian Karst, which is otherwise quite poor in Eneolithic metal finds, significantly enhances the knowledge of prehistoric development in this specific settlement territory at the beginning of the Eneolithic. 


\section{Doc. PhDr. Jaroslav Peška, Ph.D.}

- Archeologické centrum Olomouc, U Hradiska 42/6, 77900 Olomouc, Česká republika peska@ac-olomouc.cz
PhDr. Milan Salaš, CSc., DSc.

- Archeologický ústav, Moravské zemské muzeum Zelný trh 6, 65937 Brno, Česká republika msalas@mzm.cz 